\title{
Geologic Map of the Golden Throne Quadrangle, Wayne and Garfield Counties, Utah
}

Daniel H. Martin

Brigham Young University - Provo

Follow this and additional works at: https://scholarsarchive.byu.edu/etd

Part of the Geology Commons

\section{BYU ScholarsArchive Citation}

Martin, Daniel H., "Geologic Map of the Golden Throne Quadrangle, Wayne and Garfield Counties, Utah" (2005). Theses and Dissertations. 646.

https://scholarsarchive.byu.edu/etd/646

This Thesis is brought to you for free and open access by BYU ScholarsArchive. It has been accepted for inclusion in Theses and Dissertations by an authorized administrator of BYU ScholarsArchive. For more information, please contact scholarsarchive@byu.edu, ellen_amatangelo@byu.edu. 


\title{
GEOLOGIC MAP OF THE GOLDEN THRONE QUADRANGLE, WAYNE AND GARFIELD COUNTIES, UTAH
}

\author{
by
}

\author{
Daniel Holt Martin
}

\begin{abstract}
A thesis submitted to the faculty of Brigham Young University in partial fulfillment of the requirements for the degree of Master of Science
\end{abstract} Department of Geology Brigham Young University December 2005 


\title{
BRIGHAM YOUNG UNIVERSITY
}

\section{GRADUATE COMMITTEE APPROVAL}

\author{
of a thesis submitted by \\ Daniel Holt Martin
}

This thesis has been read by each member of the following graduate committee and by majority vote has been found to be satisfactory.

Date

Date

Date
Thomas H. Morris, Chair

Bart J. Kowallis

Scott M. Ritter 


\section{BRIGHAM YOUNG UNIVERSITY}

As chair of the candidate's graduate committee, I have read the thesis of Daniel H. Martin in its final form and have found that (1) its format, citations, and bibliographical style are consistent and acceptable and fulfill the university and department style requirements; (2) its illustrative materials including figures, tables, and charts are in place; and (3) the final manuscript is satisfactory to the graduate committee and is ready for submission to the university library.

Date

Accepted for the Department
Thomas H. Morris

Chair, Graduate Committee
Bart J. Kowallis

Graduate Coordinator

Accepted for the College

G. Rex Bryce

Associate Dean, College of Physical and Mathematical Sciences 


\begin{abstract}
GEOLOGIC MAP OF THE GOLDEN THRONE QUADRANGLE, WAYNE AND GARFIELD COUNTIES, UTAH
\end{abstract}

\author{
Daniel Holt Martin \\ Department of Geology \\ Master of Science
}

The Golden Throne Quadrangle is located within Capitol Reef National Park, south-central Utah. Geologic mapping of this 1:24,000 scale 7.5 minute quadrangle began in 2003 as the National Parks Service desired to have geologic maps at this scale produced within the park.

Stratigraphically, ten bedrock formations and ten Quaternary deposits are exposed within the Golden Throne Quadrangle. Geologic formations range in age from Permian to Jurassic. This map contains details not included on previous geologic maps including; the members of the Carmel, Chinle, and Moenkopi Formations. Additionally, the Page Sandstone is herein mapped as an independent unit.

Structurally the Golden Throne Quadrangle encompasses most of the southern quarter of the Miners Mountain uplift. The crest of this southwest verging uplift is cut by 
the left-lateral strike-slip Teasdale Fault zone. Preparation of a cross-section through the axis of the uplift within the quadrangle has not permitted the use of usual faulting and folding mechanisms (i.e. fault-bend folds and fault-propagation folds) for the creation of the uplift. Two structural models can account for the geometries observed in the field. The first model is a high angle reverse basement fault; the second model is a fold over an inverted basin.

The Jurassic Page Sandstone, in the Golden Throne Quadrangle, is composed of the Harris Wash and Thousand Pockets Members, which are divided by the Judd Hollow Tongue, a member of the overlying Carmel Formation It represents an erg deposit and is primarily composed of eolian sandstone. Study of the formation within the Golden Throne Quadrangle helped in the understanding of its local characteristics. Previous research has helped to develop a regional stratigraphic framework for the Page Sandstone. This study cannot be easily incorporated into the regional framework of previous studies. In order to fully understand the sedimentology of the Page Sandstone additional research will need to be accomplished. 


\section{PREFACE}

The thesis is divided into two chapters and four appendices. Both chapters are complete with their own illustrations and references. Appendix A, the geological map and legend, will be published by the Utah Geological Survey.

Chapter 1 contains a detailed overview of the preparation of the geologic map of the Golden Throne Quadrangle. It contains a summary of previous research conducted in the area. It also contains a description of methods used to create the map, and lists and discusses the important conclusions observed within this process. It includes a list of mappable geologic units which can be found within the quadrangle, and a discussion on the structure of the quadrangle.

Chapter 2 is a review of all findings pertaining to the research on the Page Sandstone. It includes an explanation of previous work, description of this study's meaningful findings, discussion about problems encountered with respect to previous research, and recommendations of future work to be accomplished.

Appendix A is a paper copy of the geologic map and legend. Appendix B is a diagram displaying the five digitized measured sections of the Page Sandstone. Appendix $\mathrm{C}$ is a data $\mathrm{CD}$ containing digital files of the geologic map, map legend, Page Sandstone correlation diagram, and copy of this thesis. Appendix D is a collection of important and interesting photos taken within the Golden Throne Quadrangle. 


\section{ACKNOWLEDGMENTS}

First of all I would like to thank my thesis advisor Tom Morris for his support and friendship throughout all my time at Brigham Young University; especially for his patience, understanding, and encouragement through the trials I have experienced during the last year of this thesis work. I would also like to thank my parents Kerry and Virginia Martin for the love and support that they have shown to me throughout my life. Dad, thanks for teaching me to love nature and to wonder how the world works, Mom thank you for the wonderful example of how to live a beautiful life. Thanks are also extended to James Eddleman for his insight, enthusiasm, and humor; Ron Harris for his assistance on the subsurface portion of the study; Sam Sorber for his valuable insights and hard work; Grant Willis of the Utah Geological Survey for his assistance in the map preparation and support for publishing this map; Helmut Doelling also of the Utah Geological Survey for his valuable suggestions which have greatly increased the quality of this map; Tom Clark of Capitol Reef National Park for his logistical assistance and mentoring; and the people of the Department of Geology at Brigham Young University for their assistance and instruction. I would also like to thank all the institutions who helped fund this research which include; the United States National Park Service, the United States Geologic Survey, and the College of Physical and mathematical Sciences at Brigham Young University. Lastly, I want to thank my wife Becca Martin for her love, 
her assistance in the field, and her willingness to let me spend so much time away working on this project. 


\section{TABLE OF CONTENTS}

ABSTRACT




\section{LIST OF FIGURES}

1 Index map of Capitol Reef National Park and the Golden Throne Quadrangle.........12

2. Stratigraphy of the Golden Throne Quadrangle................................. 17

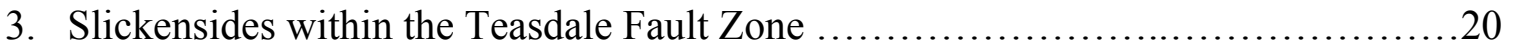

4. Fault-bed fold and fault-propagation fold diagrams.............................24

5. Folds caused by high angle reverse thrust and folds over inverted basins...........25

6. Members of the Page Sandstone............................................. 31 


\section{CHAPTER 1}

GEOLOGIC MAP OF THE GOLDEN THRONE QUADRANGLE, WAYNE AND GARFIELD COUNTIES, UTAH 


\section{INTRODUCTION}

Capitol Reef National Park, located in south-central Utah, was created in 1971 in order to protect and promote the geology and natural history of the Waterpocket Fold region. The Golden Throne Quadrangle is located mostly within the boundary of the national park (Figure 1). The landscape of the Golden Throne Quadrangle is dominated by the steep Western Escarpment of the Waterpocket Fold, at the crest of which sits a giant monolith called the Golden Throne. It is a spectacular specimen of golden Navajo and Page Sandstone, windswept and stained with desert varnish. It is this feature for which the quadrangle was named.

The Golden Throne Quadrangle contains the Scenic Drive road. It is the only paved road, other than Utah Highway 24, in the park. This road provides the only easy access into the center of the park and is therefore heavily traveled by park visitors. The Golden Throne Quadrangle was designated as a high priority for geologic mapping because of its relatively high visitation along Scenic Drive. Along with high visitation, park officials desired to have a geologic map for park service and public education, for facility expansion planning, for identification of geologic hazards, and to provide a more accurate geologic map for biological studies.

Support for mapping in the Golden Throne area has been provided by the U.S. National Park Service, the U.S. Geological Survey’s EDMAP program (Award No. 03HQAG0035), the Utah Geological Survey, Brigham Young University College of Physical and Mathematical Sciences, and the Brigham Young University Department of Geology. This map has been accepted for publication and will be published by the Utah Geological Survey. 


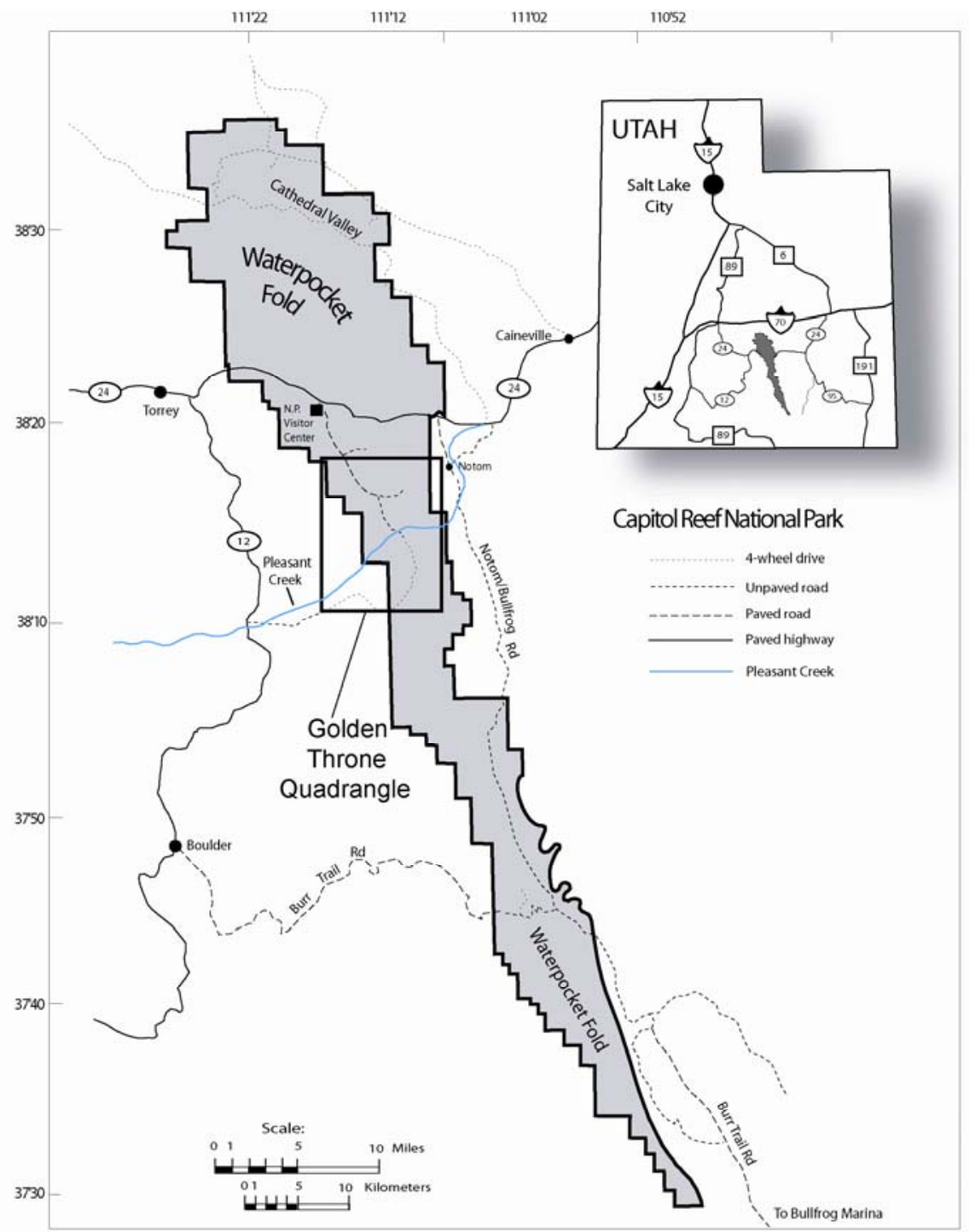

Figure 1. Reference map of Capitol Reef National Park and the Golden Throne Quadrangle (Modified from Morris et al., 2000).

\section{BACKGROUND AND PREVIOUS WORK}

Study of the geology in and around Capitol Reef National Park began with the first explorers/geologists who visited the area. Howell (1875), Gilbert (1877), and Dutton's (1880) studies during the late 1800's were among the first to describe and decipher the complex and stunning geology of this area. Gregory and Anderson's (1939) 
paper contained the first detailed unit descriptions, stratigraphic analysis, measured sections, and geomorphic information of the Capitol Reef area.

The first detailed geologic maps $(1: 24,000)$ of the area were produced by Smith et al. (1957) in association with a study of uranium-bearing rocks found in the region. These maps were funded by the U.S. Atomic Energy Commission. These maps were used as the base map for a 1:62,500 scale regional geologic map included with a U.S. Geological Survey Professional Paper (Smith et al., 1963). Billingsley et al. (1987) published a 1:62,500 scale map of the entire national park, which added greater understanding to the geology of the park.

Renewed interest in mapping in the park began in 2001 with the Fruita Quadrangle (McLelland et al. 2002). Additional mapping was requested by the National Park Service as they desired to have published and updated 1:24,000 scale 7.5 minute geologic maps of the park. The Golden Throne Quadrangle is the second in a series of three 1:24,000 scale 7.5 minute quadrangles completed by Graduate Students from Brigham Young University. Also included are the Fruita Quadrangle and the Twin Rocks Quadrangle.

This map includes some important details not included in previous maps:

- Mapping separately the members of the Carmel Formation; the Paria River Member, the Lower Windsor Member (gypsum member), and the Upper Windsor Member (banded member).

- Mapping separately the members of the Chinle Formation; the Shinarump Conglomerate, the Monitor Butte Member, the Petrified Forest Member, and the Owl Rock Member. 
- Mapping separately the Members of the Moenkopi Formation; the Black Dragon Member, the Sinbad Limestone, the Torrey Member, and the Moody Canyon Member.

- The Page Sandstone mapped as an independent unit. The Page Sandstone was mentioned in the unit descriptions in the map by Billingsley et al. (1987) but was not officially mapped as a separate unit until (McLelland et al., 2002).

- Greater detail of Quaternary deposits such as; two levels of alluvial deposits (Qa11, Qa12), designation of two basalt boulder alluvial terrace levels within the Glen Canyon section of Pleasant Creek (Qatb1, Qatb2), and mapping of landslide deposits (Qms).

- More detailed hypotheses of subsurface folding mechanism and geometry of the Miners Mountain uplift (included with the map legend, Appendix A, Plate 2).

\section{MAPPING METHODOLOGY}

Data collection for the map was conducted on two fronts; mapping in the field and the study of 1:12,000 scale true-color aerial photos. Field maps and photo interpretations were then digitized using GIS software.

Field mapping of the quadrangle was accomplished during 2003, 2004, and 2005. Field mapping methods included: creating paper field maps showing bedrock and Quaternary geology contacts on the 7.5 minute topographic map of the Golden Throne Quadrangle; rock formation study to determine lithology, color, grain size, and formational contacts for the creating of unit descriptions; and the gathering of structural information such as strike and dip measurements and fault information for creating a geologic cross-section. Strike and dip measurements were made in as many areas as 
possible, however the formations of the Glen Canyon Group posed a challenge due to their inaccessibility and lack of good bedding planes. Special attention in obtaining abundant strike and dip data was paid to the Teasdale Fault/Pleasant Creek area in order to aid in accurate cross-section construction.

1:12,000 scale true-color aerial photos of Capitol Reef National Park were taken in 2002 specifically for the National Park Service use. These aerial photos were very useful in mapping because large portions of the quadrangle are very remote, rugged, and accessible only by hiking great distances. Bedrock formation contacts, Quaternary deposits, and fault traces were mapped in part with the aid of these photos.

Further modifications and edits to the map were made using VR1 mapping software at a workstation located at the Utah Geologic Survey (UGS) with input from UGS Geologist Helmut Doelling in order to prepare the map for final acceptance and publication.

\section{STRATIGRAPHY}

\section{Bedrock Geology}

The Golden Throne Quadrangle contains bedrock formations and members mappable on a 1:24,000 scale, ranging in age from the Middle Permian to Upper Jurassic (Figure 2). These formations and members include:

- Cutler Group (Permian) (Pc)

- Kaibab Limestone (Permian) (Pk)

- Moenkopi Formation (Triassic) and its members:

o Black Dragon Member (Trmb)

o Sinbad Limestone Member (Trms) 
o Torrey Member (Trmt)

o Moody Canyon Member (Trmm)

- Chinle Formation (Triassic) and its members:

o Shinarump Conglomerate Member (Trcs)

o Monitor Butte Member (Trcm)

o Petrified Forest Member (Trcp)

o Owl Creek Member (Trco)

- Wingate Sandstone (Jurassic-Triassic) (JTrw)

- Kayenta Formation (Jurassic) (Jk)

- Navajo Sandstone (Jurassic) (Jn)

- $\quad$ Page Sandstone (Jurassic) (Jpc)

- The Carmel Formation (Jurassic) and its members:

o Paria River Member (Jcpr)

o Lower Windsor (gypsum) Member (Jcwg)

o Upper Windsor (banded) Member (Jcwb)

- Entrada Sandstone (Jurassic) (Je) 
(Morris et al., 2000; Jones and Blakey, 1997; Blakey et al., 1996; Hintze, 1993;

Kamola and Chan, 1988; Peterson, 1988; and Mitchell, 1985). Descriptions of

formations, members, and age data can be found on the legend of the geologic map

(Appendix A, Plate 2).

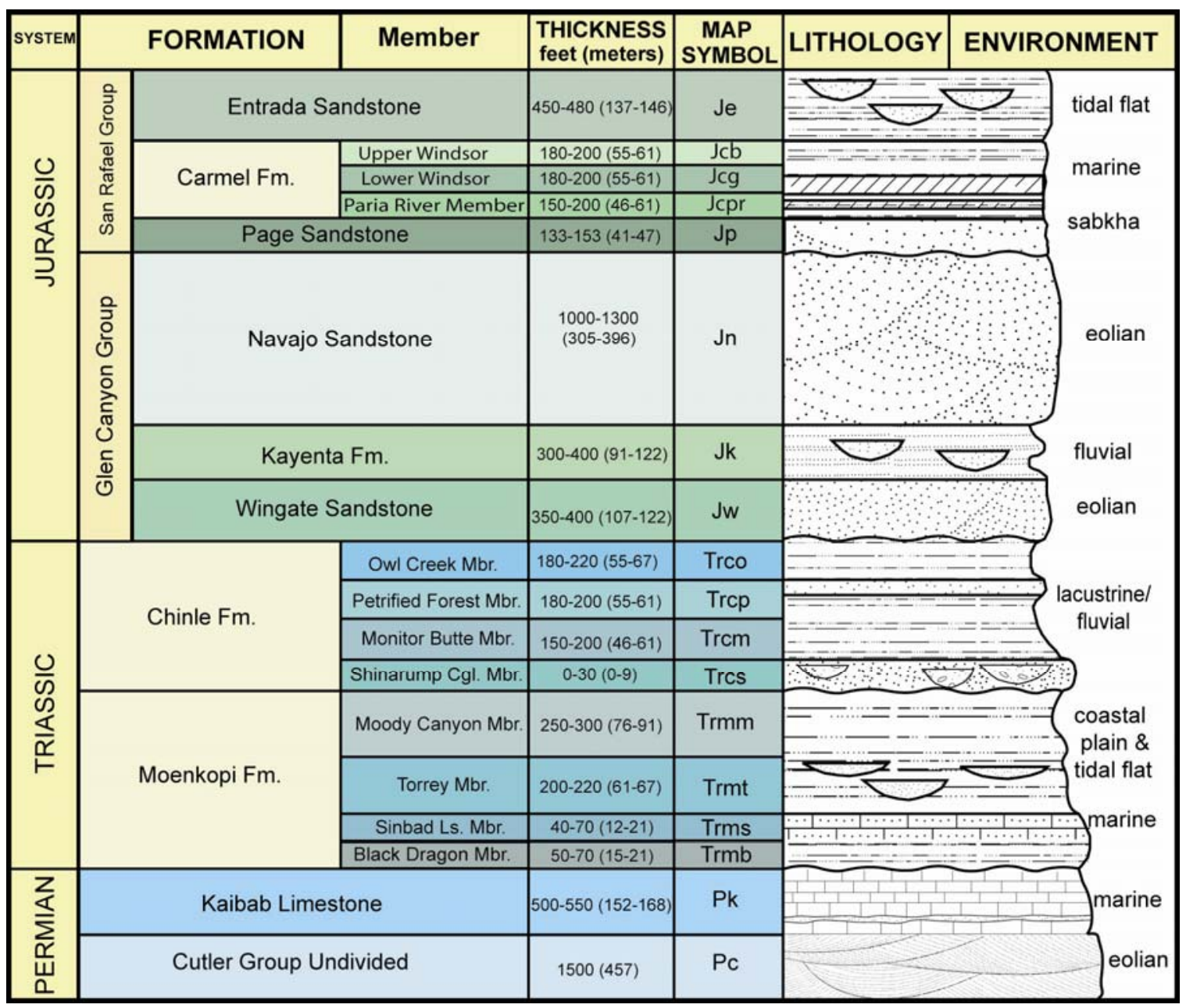

Figure 2. Stratigraphy of the Golden Throne Quadrangle (Modified from Morris et al., 2000).

\section{Quaternary Geology}

Quaternary deposits in this quadrangle have been broken into ten units. They are; alluvial and floodplain deposits (Qal), alluvial and floodplain deposits of an older river level (Qa12), talus deposits (Qmt), basalt boulder terraces (Qatb1, Qatb2 Qatbu), basalt 
boulder terrace colluvial deposits (Qmtb), terrace deposits composed of locally derived material (no basalt) (Qatl), eolian deposits (Qe), and landslide deposits (Qms). Relative age information of these units and lithologic descriptions can be found in the legend of the included geologic map (Appendix A, Plate 2).

Basalt boulder terraces found in the Pleasant Creek drainage are a deposit of special interest. Work by Eddleman (2005) has determined that basalt boulder terraces within the Waterpocket Fold section (Moenkopi Formation, Chinle Formation, Wingate Sandstone, Kayenta Formation, Navajo Sandstone, and Carmel Formation) of the river can be divided into two distinct groupings (Qatb1, Qatb2) that represent two major episodes of down-cutting of the Pleasant Creek streams. These groupings may correlate to terraces in the nearby Fremont river drainage. An explanatory summary of the work done by Eddleman (2005) on the basalt boulder terraces, and their correlation to the landscape evolution of the Pleasant Creek drainage will be included with the map legend of the Golden Throne Quadrangle (Appendix A, Plate 2).

\section{STRUCTURE}

Capitol Reef National Park encompasses a geographic feature historically called the Waterpocket Fold. This fold is composed of two distinct structures, the Miners Mountain uplift to the north and the Circle Cliffs uplift to the south. The Miners Mountain uplift has only been recently recognized as a separate uplift from the larger Waterpocket Fold (Bump et al., 1997). This quadrangle lies just north of the transition zone between the two uplifts. The Miners Mountain uplift was formed during the Laramide Orogeny which occurred during the Late Cretaceous to Early Tertiary. It is a doubly-plunging anticline whose axis trends $\mathrm{N} 60^{\circ} \mathrm{W}$ (Bump and Davis, 2003). This large 
fold ( 27 miles northwest-southeast by 12 miles northeast-southwest) has been described as having three structural components; the gently dipping $\left(10^{\circ}-15^{\circ}\right)$ backlimb known as the Waterpocket Monocline, the anticlinal crest known as the Miners Mountain Anticline, and the steeply dipping $\left(30^{\circ}-60^{\circ}\right)$ forelimb of the fold called the Teasdale Monocline (Billingsley et al., 1987; Anderson and Barnhard, 1986). Studies of faults, fractures, and deformation bands found within the uplift have shown that this fold was formed by left hand oblique slip, likely associated with a basement-initiated reverse fault (Bump and Davis, 2003; Anderson and Barnhard, 1986). Direction of maximum compression ( $\sigma 1)$ was determined to be $\mathrm{N} 60^{\circ} \mathrm{E}-\mathrm{N} 70^{\circ} \mathrm{E}$ (Bump and Davis, 2003; Anderson and Barnhard, 1986). The Golden Throne Quadrangle encompasses a portion of the lower quarter of the Miners Mountain uplift.

\section{Teasdale Fault}

The Teasdale Fault is a prominent fault which cuts the rim of the Teasdale Monocline along much of its trace. It runs, for most of its length, parallel to the forelimb of the fold (roughly northwest southeast). Within the Golden Throne Quadrangle, this fault curves eastward and crosses the anticlinal crest of the Miners Mountain uplift just south of Pleasant Creek. Previous maps have shown this fault to be a normal fault (Billingsley, 1987; Smith et al., 1963). Although the fault does have mostly normal offset, it also has a component of left lateral strike-slip motion. This is recorded by slickensides in the fault zone (Figure 3) and a change of apparent offset from down to the south, to down to the north, as the fault crosses the anticlinal crest of Miners Mountain. The strike-slip component is thought to be a consequence of left lateral basement 


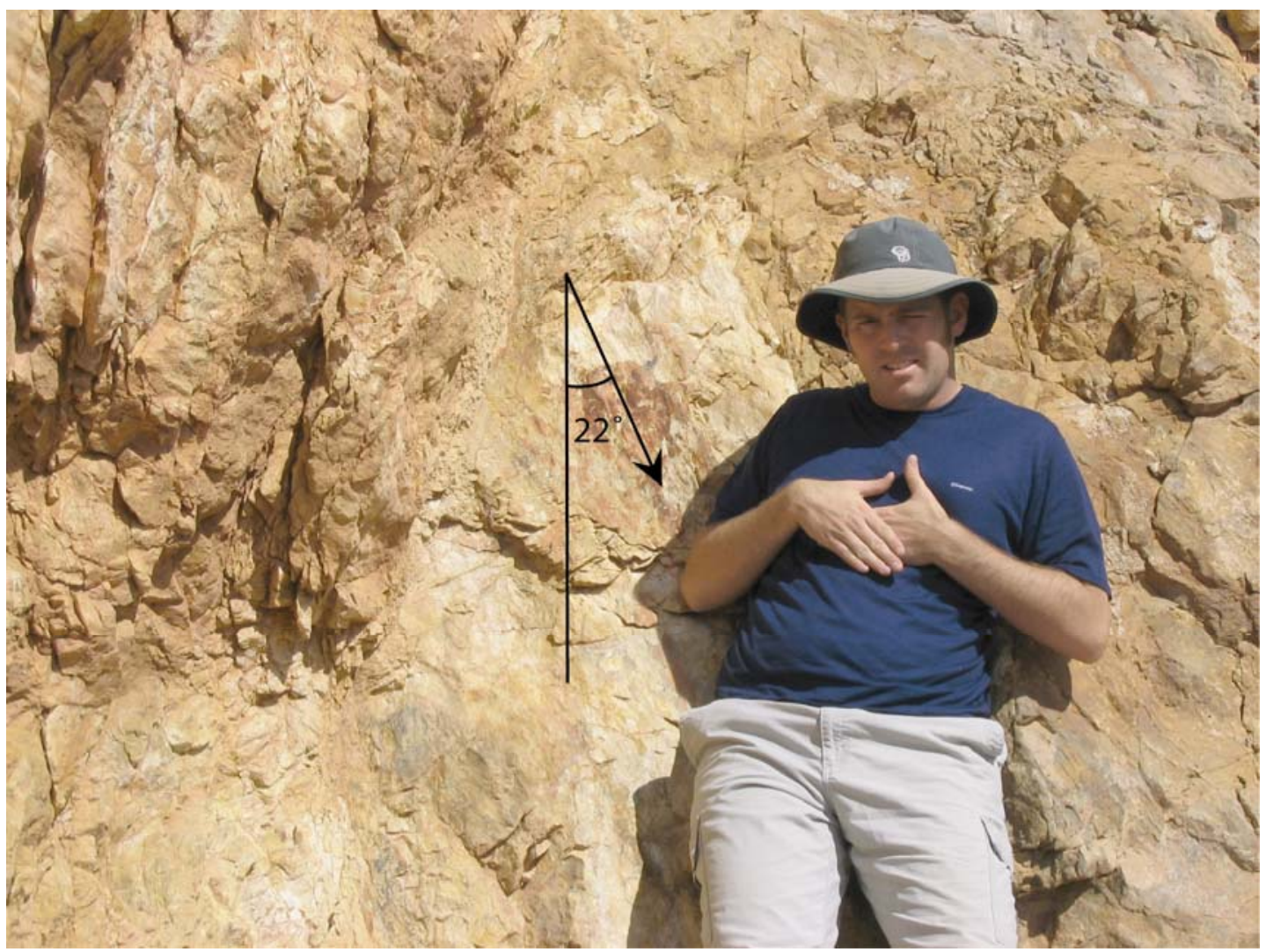

Figure 3. Slickensides demonstrating left-lateral movement along the hanging wall of the Teasdale Fault with a rake of $22^{\circ}$. Photo taken at the point where Pleasant Creek intersects the Fault Trace.

movement. The change of direction in the fault zone from southeast to east is thought to be a result of the wrench zone created by the eastward verging Circle Cliffs uplift.

The interpretation of the normal component of offset encountered in the Pleasant Creek area depends on the subsurface folding mechanism model used. The offset may be related to fold accommodation faulting which terminates into the neutral surface of the fold in the inverted basin model, or is directly connected to the underlying large scale fault structure in the basement reverse fault model. 


\section{Subsurface Geometry}

Only a few models have been proposed to describe the formation of the Miners Mountain uplift. In their cross-section Smith et al. (1963) only project far enough into the subsurface to show exposed bedding and do not show the fold-causing fault. Billingsley et al. (1987), show a simple high-angle reverse fault as the mechanism of the fold. The simple high angle basement fault is probably correct, however, it was hoped that this present study would be able to shed some additional light on the question.

Several factors increase the difficulty of construction and interpretation of a crosssection in the Golden Throne Quadrangle area, and perhaps make the area less representative of the larger Miners Mountain uplift. First, the uplift morphology within the Golden Throne Quadrangle is unique. It has a relatively shallow dipping $\left(60^{\circ}\right)$ forelimb, very short toplimb, and extremely long backlimb. Second, the Teasdale Fault for most of its length is parallel to the forelimb of the fold (roughly northwest southeast). Near Pleasant Creek it suddenly turns to the east bisecting the southern portion of the structure. Third, the northwest-southeast trending forelimb sharply turns south near Sheets Draw. This is best observed where the Shinarump Conglomerate bends sharply south. Lastly, in this area the forelimb and backlimb are not parallel; therefore any straight cross-section would intersect at least one of the limbs of the uplift at an angle other than perpendicular. This creates, in cross-sectional view, limbs which are inaccurately long or short.

A cross-section has been constructed that bisects the fold near the Pleasant Creek area. Hypotheses of the subsurface structure have been developed using the exposed fold morphology to model a likely subsurface geometry. Careful study of the exposed 
structural information was done in order to construct a cross-section which most accurately interprets the subsurface relationships. Models such as fault-bend folds and fault-propagation folds (van der Pluijm and Marshak, 1997; Bump, 2003; Tindall and Davis. 1999) must be ruled out because of the geometric constraints (Figure. 4) encountered in this portion of the Miners Mountain uplift. Two folding models have been identified which fit the narrow geometric requirements. These models are (1) - high angle reverse faults initiated in the basement proposed by Billingsley et al. (1987), and (2) - a fold occurring over an inverted basin (Figure 5).

1. Davis (1978) used a clay and pine board experiment to model the effect of a high angle reverse fault on an overlying succession of strata. This model showed that immediately over the tip of the fault the strata were folded and faulted at a high angle. However, further up section the degree of folding dissipated and was taken up in reverse faults and flexural flow in the fold area. The reverse faults and the flexural flow caused the dip of the forelimb of the surface geometry to not be as severe as the underlying structure.

The Miners Mountain uplift may be similar to this model because of the good fit of the fold geometry. The Teasdale Fault and other smaller faults can be explained as

A.

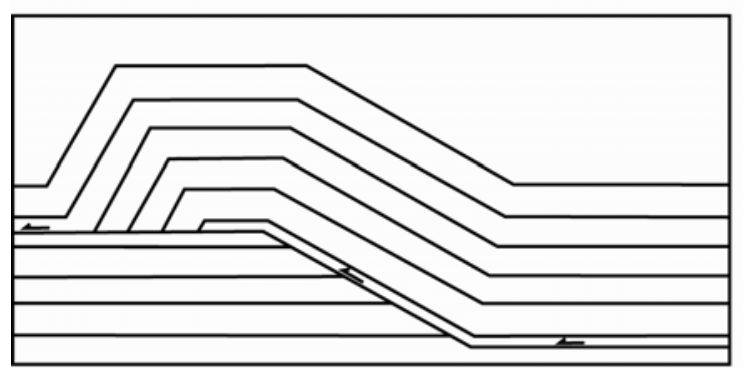

B.

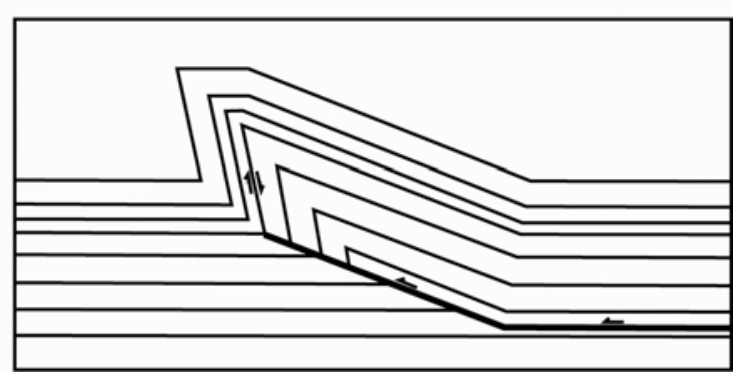

Figure 4. Schematic diagrams of a fault-bend fold (A) and fault-propagation fold (B), after van der Pluijm and Marshak (1997). A. Fault-bend fold morphology displays a shallow forelimb, long toplimb, and backlimb that mirrors the fault ramp. B. Faultpropagation fold morphology displays an overturned forelimb, short toplimb, and a backlimb that mirrors the fault ramp. Neither of these models fit the geometric constraints of the Miners Mountain Uplift within the Golden Throne Quadrangle. 
A.

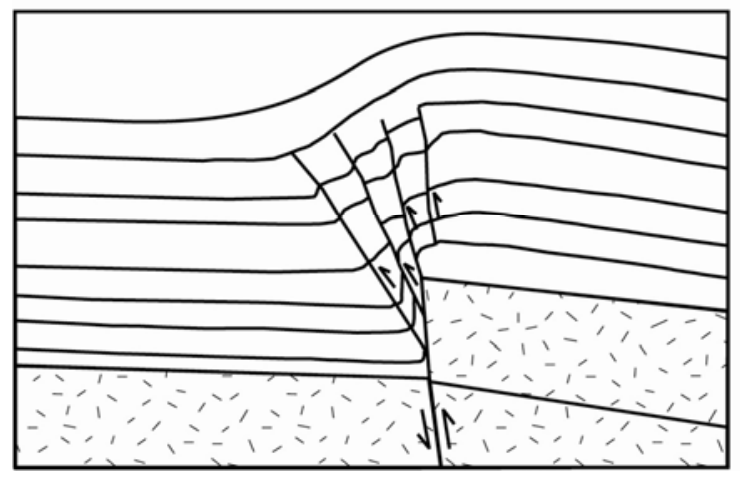

B.

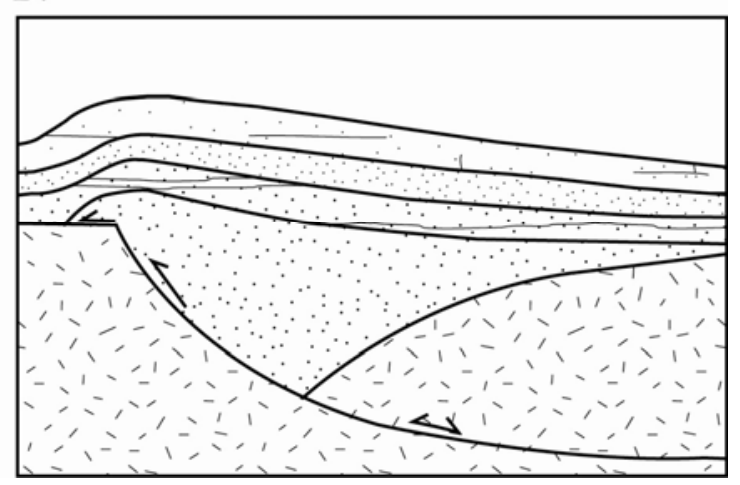

Figure 5. A. Schematic diagram showing a high angle reverse thrust into overlying strata, after Davis (1978). Fold morphology shows that directly over the tip of the fold the forelimb is dipping at a high angle and faulted. Higher in the section the degree of folding is taken up by reverse faults which lessen the steepness of the forelimb. This model has a short toplimb and a potentially long backlimb. This morphology is a better fit with the Miners Mountain Uplift within the Golden Throne Quadrangle. B. Schematic figure demonstrating folding which occurs as a reactivated normal fault injects synrift sediments into the overlying sediment package, after McClay and Buchanan (1992). Fold morphology displays a shallow dipping forelimb, short toplimb, and a long backlimb that mirrors basin morphology. This morphology also fits well with the Miners Mountain Uplift in the Golden Throne Quadrangle.

reverse faults by this model. Having been successfully modeled in experiments, examples of these types of fault geometries can readily be found in nature. For example, Laramide aged structures such as Rattlesnake Mountain and the Bighorn Uplift (Wyoming) both display this fold geometry at depth.

2. Folds over inverted basins offer an alternative model. These types of uplifts have geometries that are similar to the Miners Mountain Fold (McClay and Buchanan, 1992). An inverted-basin fold forms when a listric normal fault is reactivated with reverse fault motion and displaces syn-rift sediments into the overlying rock column. It has been proposed that faults causing Laramide uplifts are reactivated ancient normal faults (Marshak et al., 2000). Rift zones adjacent to normal faults likely contain syn-rift sediments. 
In surrounding areas, deposition of syn-rift sediments have occurred during the Pennsylvanian (Paradox and Oquirrh basins) (Hintze, 1993) and during the Precambrian (Grand Canyon area) (Huntoon et al., 1996). Well data precludes thick successions of Pennsylvanian age rock in the Capitol Reef region (Hintze, 1993). The Grand Canyon area does contain significant accumulations of Precambrian aged syn-rift sediments (Grand Canyon Series) and may be a similar situation. Precambrian-age rock is not exposed and little well data exists in the area between the Uncompahgre Uplift in Colorado and the Grand Canyon in Arizona (Hintze, 1993). The lack of information about the Precambrian section of the Colorado Plateau does not rule out the possibility that syn-rift sediments may exist in some locations. It is possible that a Precambrian rift zone with syn-rift sediments exists in the Capitol Reef area, and that reactivation during later compressional events (Laramide Orogeny) of these earlier rift zones has caused the Miners Mountain uplift. In this model the Teasdale Fault would initiate a fold accommodation fault and terminate into the neutral surface of the fold.

\section{CONCLUSIONS}

The geologic map and map legend presented in this thesis summarize the stratigraphic and structural geology of the Golden Throne Quadrangle. The following conclusions can be determined from this map:

- This edition of the map contains the members of the Moenkopi, Chinle, and Carmel Formations.

- Eighteen mappable bedrock formations and members ranging from Permian to Jurassic in age are found within the map area.

- Ten Quaternary geologic units are found in the map area. 
- Basalt boulder terraces within the Waterpocket Fold portion of the drainage can be divided into two terrace levels (Qatb1, Qatb2) representing two down-cutting episodes possibly linked to climate fluctuations.

- The quadrangle contains a northwest-southeast trending Laramide aged monoclinal structure.

- Morphologic constraints preclude simpler models such as fault-bend folds and fault-propagation folds from being the mechanism of folding of the quadrangle.

- The fold mechanism of the uplift may either be caused by a basement thrust fault or a fold over an inverted basement fault.

- The Teasdale Fault has some component of strike-slip motion and bisects the crest of the fold. It is either connected to the deeper structure, or terminates into the neutral surface of the fold. 


\section{REFERENCES}

Anderson, R.E., and Barnhard, T. P., 1986, Genetic relationship between faults and folds and determination of Laramide and neotectonic paleostress, western Colorado Plateau-transition zone, central Utah: Tectonics, v. 5, n. 2, p. 335-357.

Billingsley, G.H., Huntoon, P.W., and Breed, W.J., 1987, Geologic map, of Capitol Reef National Park and vicinity, Emery, Garfield, Millard, and Wayne Counties, Utah: Utah Geological and Mineral Survey Map 87, Scale1:62, 500.

Blakey, R.C., Havholm, K.G., and Jones, L.S., 1996, Stratigraphic analysis of eolian interactions with marine and fluvial deposits, Middle Jurassic Page Sandstone and Carmel Formation, Colorado Plateau, USA: Journal of Sedimentary Research, v. 66, n. 2, p. 324-342.

Bump, A.P., 2003, Reactivation, trishear modeling, and folded basement in Laramide uplifts: implications for the origins of intra-continental faults: GSA Today, p. 410 .

Bump, A.P, and Davis, G.H., 2003, Late Cretaceous-Early Tertiary Laramide deformation of the northern Colorado Plateau, Utah and Colorado: Journal of Structural Geology, 25 p. 421-440.

Bump, A. P., Ahlgren, S. G., and Davis, G. H., 1997, The Waterpocket Fold, a tale of two uplifts, Capitol Reef National Park, Utah: in Eos, Transactions of the American Geophysical Union, v. 78, p. F701.

Davis, G.H., 1978, Monocline fold pattern of the Colorado Plateau: Geological Society of America, Memoir 151, p. 215-233

Dutton, C.E., 1880, Geology of the high plateaus of Utah: United States Geographical and Geological Survey Rocky Mountain region, p. 276-282, and atlas sheet 2.

Eddleman, J.R., 2005, Elevation, longitudinal profile, and Schmidt Hammer analysis of strath terraces through Capitol Reef National park; Bed rock channel response to climate forcing?: Master's Thesis, Brigham young University p. .

Gilbert, G.K., 1877, Geology of the Henry Mountains: United States Geographical and Geological Survey Rock Mountain region (Powell), p. 160, $2^{\text {nd }}$ edition.

Gregory, H.E., and Anderson, J.C., 1939, Geographic and geologic sketch of the Capitol Reef region, Utah: Bulletin of the Geological Society of America, v. 50, p. 18271850 . 
Hintze, L.F., 1993, Geologic history of Utah: Brigham Young University Geology Studies, Special Publication 7.

Howell, E.E., 1875, Report on the geology of Utah, Nevada, Arizona, and New Mexico examined in the years 1872 and 1873: In Wheeler, G.M., (Ed), Geographical and geological explorations and surveys west $100^{\text {th }}$ meridian: Geology, v. 3, 265-289.

Huntoon, P. W., Billingsley, G.H., Sears, J.W., Lig, B.R., Karlstrom, K.E., Williams, M.L., and Hawkins, D., 1996, Geologic map of the eastern part of the Grand Canyon National Park, Arizona: Grand Canyon Association.

Jones, S.L., and Blakey, R.C., 1997, Eolian-fluvial interaction in the Page Sandstone (Middle Jurassic) in south-central Utah, USA- a case study of erg margin processes: Sedimentary Geology, 109, p. 181-198.

Kamola, D.L., and Chan, M.A., 1988, Costal dune facies, Permian Cutler Formation (White Rim Sandstone), Capitol Reef National Park area, southern Utah: Sedimentary Geology, 56, p. 341-356.

Marshak, S., Karlstrom, K., Timmons, J. M., 2000, Inversion of Proterozoic extensional faults: An explanation for the pattern of Laramide and Ancestral Rockies intracratonic deformation, United States: Geology 28, p. 735-738.

McClay, K.R., and Buchanan, P.G., 1992, Thrust faults in extensional basins, In: McClay, K.R., (ed), Thrust Tectonics, Chapman and Hall, p. 94-104.

McLelland, B.E., Morris, T.H., and Martin, D.H., 2002, Geologic Map of the Fruita Quadrangle, Wayne County, Utah: Utah Geological Survey, in press. 1:24,000.

Mitchell, G.C., 1985, The Permian-Triassic stratigraphy of the northwest Paradox basin area, Emery, Garfield, and Wayne Counties, Utah: The Mountain Geologist, v. 22, n. 4, p. 149-166.

Morris, T.H., Manning, V., and Ritter, S.M., 2000, Geology of Capitol Reef National Park, Utah: In Sprinkel, D.A., Chidsey, T.C., Jr., and Anderson, P.B., (eds), Geology of Utah's parks and monuments: Utah Geological Association Millennium Guidebook, Publication 28, p. 84-105.

Peterson, F., 1988, Stratigraphy and nomenclature of Middle and Upper Jurassic rocks, western Colorado Plateau, Utah and Arizona: United States Geological Survey Bulletin 1633-B, p.13-56.

Smith, J.F., Jr., Huff, L.C., Hinrichs, E.N., and Luedke, R.G., 1957, Preliminary geologic map of the Notom 4 NW Quadrangle, Utah: United States Geological Survey Mineral Investigations Field Studies Map MF 113, 1:24,000. 
Smith, J.F., Jr., Huff, L.C., Hinrichs, E.N., and Luedke, R.G., 1963, Geology of the Capitol Reef area, Wayne and Garfield Counties, Utah: Geological Survey Professional Paper 363.

Tindall, S.E., and Davis, G.H., 1999, Monocline development by oblique-slip faultpropagation folding: the east Kaibab Monocline, Colorado Plateau, Utah: Journal of Structural Geology, 21, p. 1303-1320.

van der Pluijm, B.A., and Marshak, S., 1997, Earth Structure, An introduction to structural geology and tectonics: WCB/McGraw Hill, p. 377-379. 
CHAPTER 2

STRATIGRAPHIC ANALYSIS OF THE PAGE SANDSTONE WITHIN THE GOLDEN THRONE QUADRANGLE 


\section{ABSTRACT}

The Jurassic Page Sandstone in the Golden Throne Quadrangle crops out in many places as the capstone of the huge monoliths which tower above the Waterpocket Fold. In the Capitol Reef area the Page Sandstone is composed of the Harris Wash and the Thousand Pockets Members which is divided by the Judd Hollow Tongue, a member of the overlying Carmel Formation. It represents an erg deposit, and is primarily composed of eolian sandstone; however it does contain some amounts of siltstone, shale, and limestone. The Page Sandstone lies stratigraphically above the Navajo Sandstone. This contact has been called the $\mathrm{J} 2$ unconformity and displays pervasive polygonal fractures.

Study of the formation within the Golden Throne Quadrangle helped in the understanding of its local characteristics. Previous research has helped to develop a regional stratigraphic framework for the Page Sandstone. This study cannot be easily incorporated into the regional framework of previous studies. In order to fully understand the sedimentology of the Page Sandstone additional research will need to be accomplished.

\section{INTRODUCTION}

The Page Sandstone is the capstone for the Golden Throne and other surrounding monoliths that are at the crest of the Waterpocket Fold. The scene of the Golden Throne rising out of the Utah desert is one of the most awe inspiring in all the Colorado Plateau. The Page Sandstone was recently mapped as an independent unit in the Capitol Reef area (McLelland et al., 2002). The Page Sandstone was deposited by eolian processes during the Bajocian and Bathonian Stages of the Middle Jurassic Series (Jones and Blakey, 1997). The Page Sandstone is separated from the Navajo Sandstone by an unconformity 


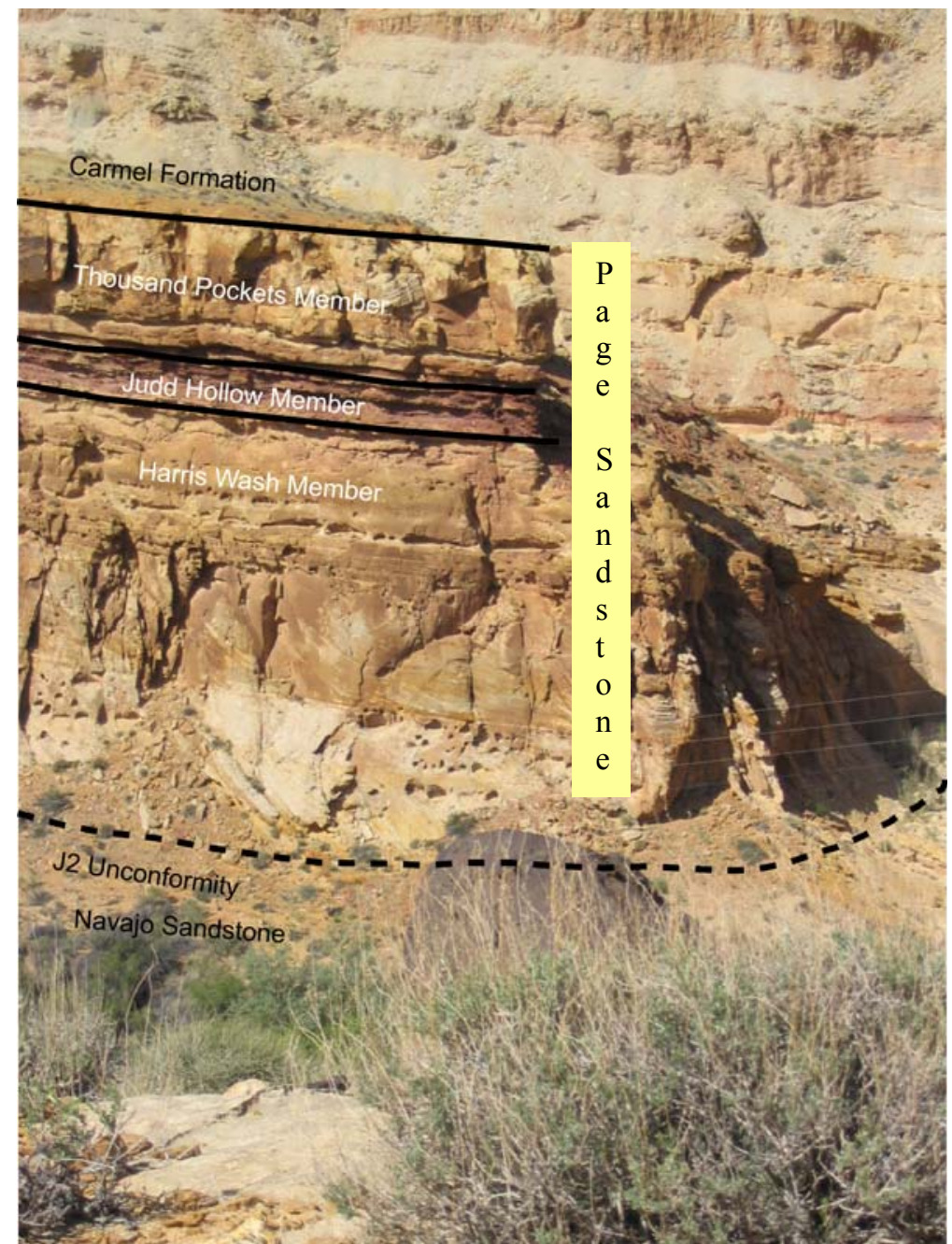

Figure 6. Annotated photo displaying the members of the Page Sandstone. Taken at the Fremont River section.

which displays pervasive

polygonal fracture sets. This contact has been called the $\mathrm{J} 2$ unconformity (Pipiringos and O’Sullivan 1978).

\section{In order to better}

describe and more accurately map the Page Sandstone in the Golden Throne

Quadrangle five sections of the formation were measured in and around the quadrangle. It was also hoped that the information gleaned from the measured sections could be used to correlate the stratigraphy and sedimentology of the Page Sandstone to work by previous researchers of the Page Sandstone.

\section{BACKGROUND/PREVIOUS REASEARCH}

The Page Sandstone has been rigorously studied in various localities in Utah and Arizona concentrating around the Page, Arizona and Lake Powell regions, and the Boulder, Utah and Escalante, Utah regions (Jones and Blakey, 1997; Blakey et al., 1996; 
Havholm and Kocurek, 1994; Capps, 1990). These papers addressed rock type, sequence-stratigraphy, sedimentology, and age of the formation, but focused on areas south and west of the Golden Throne Quadrangle.

Meaningful surfaces called super bounding surfaces or super surfaces have been observed within the Page Sandstone. Super surfaces are defined as regionally extensive (up to 100 miles in Page Sandstone examples) bounding surfaces which represent a hiatus in erg development (i.e. unconformities) (Kocurek, 1988). These unconformities are thought to represent the on-land expression of the maximum flood of sea level rise.

Super surfaces can be identified by any of the following characteristics: 1truncation of $1^{\text {st }}$ order bounding surfaces; 2- a pebbly lag surface; 3- a surface with evaporates, preferential cementation, and /or polygonal fractures; 4- paleosols, rhizoliths, and / or bioturbation; and 5- irregular surfaces, eroded surfaces, and / or eolian, lucustrian, fluvial, or sabkha infill (Kocurek, 1988; Capps, 1990).

A sequence stratigraphic framework has been developed for the Page Sandstone in areas ranging from Page, Arizona to Boulder, Utah (Blakey et al., 1996, Havholm and Kocurek, 1994), using super surfaces as sequence boundary markers. These studies included little information from the Capitol Reef area.

Mark Capps' Master's Thesis (1990) studied the Page Sandstone in and around Boulder and Escalante, Utah, with a small portion of work in the Capitol Reef area. His paper contained research close to the Golden Throne Quadrangle and was therefore the most relevant and most useful. The bulk of Capps' work was accomplished at least 20 and up to 100 miles southeast of the Golden Throne Quadrangle, separated by the Circle Cliffs uplift and Boulder Mountain, where he measured forty five sections. He, however 
only measured three sections in the Capitol Reef area, the nearest one at the waterfall of the Fremont River on Highway 24. Included in his thesis are several cross-sections through his study areas including one along strike with the Waterpocket Fold. In the Capitol Reef area Capps (1990) identified seven super surfaces which were displayed on the cross-section. Sections of rock between these super surfaces can be broken into six packages of rock.

\section{STRATIGRAPHY AND SEDIMENTOLOGY}

The Jurassic Page Sandstone in the Golden Throne Quadrangle has been broken into two members, the Harris Wash Member and the Thousand Pockets Member (Jones and Blakey, 1997; Blakey, personal communication)(Figure 6). The Judd Hollow Tongue, which divides the two members, has been identified as a tongue of the overlying Carmel Formation (Jones and Blakey, 1997). Additionally, work by Doug Sprinkel and Helmut Doelling (UGS, personal communication) has determined that the Judd Hollow Tongue can further be subdivided into the Judd Hollow and the Crystal Creek Members of the Carmel Formation. This division has been made based on pollen collected at the waterfall section on Utah Highway 24. For discussion purposes within this thesis the portions of Carmel Formation within the Page Sandstone will be called the Judd Hollow Tongue.

\section{Member Descriptions}

The Harris Wash Member ranges in thickness from twenty seven to thirty five meters. The member is almost entirely composed of sandstone of fine-to mediumgrained sand size and is composed dominantly of quartz. This sandstone was mostly deposited as trough-crossed and high angle trough-crossed stratified sand, with minor 
sections of planar laminated sand and massive sand. Some finer grained sediment is also in the section. This is manifested as shale and very fine crinkly bedded silt layers between the sand bodies.

The Judd Hollow Tongue ranges in thickness from two to five meters. The member is composed of red silt and shale beds with a few fine grained sandstone beds. Two measured sections include thin carbonate beds, ranging from one centimeter to fifty centimeters in thickness. Bedforms include crinkly beds, planar laminated beds, and massive beds.

The Thousand Pockets Member ranges in thickness from five to ten meters in thickness. It is mainly composed of medium- to fine-grained quartz sandstone, but does contain some siltstone and shale. Bedforms in the sandstones include: planar laminated beds, trough-cross stratified beds, and contorted bedding. The contorted bedding is of special interest as it occurs directly above the Judd Hollow Tongue and is possibly related to soft sediment deformation events caused by sea level fluctuations?

\section{STUDY METHODOLOGY}

For this study five sections within and near the Golden Throne Quadrangle were measured using a Jacob's Staff (Appendix B, Plate 3). Member characteristics such as: lithology, changes in lithology, thickness, bedforms, color, and grain size were noted. Nine facies types were identified to facilitate section interpretation. These were based on facies identified by Capps (1990) in his study. These facies types include the following:

- Cross-bedded Sandstone. This facies is composed of trough cross-stratified to high angle trough cross-stratified, medium- to fine-grained, quartz-rich sandstone. 
It makes up a large percent of the Harris Wash Member and is encountered in small amounts in the Thousand Pockets Member.

- Massive Sandstone. This facies is composed of medium- to fine-grained sandstone that displays no bedding.

- Planar Laminated Sandstone. This facies is composed of medium- to fine-grained sandstone that displays planar lamination.

- Shale. Shale beds are composed of planar laminated clay-sized particles. They are often red in color and occasionally gray-green in color. Shale beds are most often encountered in the Judd Hollow Tongue and are also encountered in other members associated with super surfaces.

- Siltstone. Siltstone beds are composed of planar laminated silt-sized particles. They are usually red in color and are most often encountered in the Judd Hollow Tongue. Siltstone beds are also encountered in other members associated with super surfaces.

- Wavy Laminated Sandstone. Wavy laminated sandstone beds are composed of sand, silt, and clay-sized particles which are irregularly bedded. They are found in the Judd Hollow Tongue, and in the other members associated with super surfaces.

- Carbonate Deposits. This facies is found in thin beds and is associated with the Judd Hollow Tongue.

- Bioturbated Horizons. These beds exhibit some type of bioturbation. 
- Contorted Bedding. This facies is composed of medium to fine sand grains. It is almost always encountered in the Thousand Pockets Member above the Judd Hollow Tongue transition.

Measured sections were digitized using Adobe Illustrator CS. Information concerning facies types, interpreted super-surface locations, member boundaries, and other surfaces was included. The sections were scaled to represent their correct spatial locations (Appendix B, Plate 3).

\section{COMPARISONS TO PREVIOUS RESEARCH}

Surfaces were observed within the Page Sandstone like those described by Kocurek (1988) and Capps (1990). During the process of measuring sections it became clear that a major challenge in comparing this project to other studies was the presence of multiple surfaces within the section that could possibly qualify as super surfaces. This problem manifests itself due to the somewhat broad definition of the super surface. The written descriptions of super surfaces in previous literature imply that the supersurfaces are easily recognized in the field. Clear correlations are, in reality, hard to recognize. It also became apparent that more measured sections were needed in this area in order to be able to follow all surfaces laterally to determine which surfaces were super surfaces. Unfortunately this further study was beyond the scope of the project and was not accomplished at this time.

The best surfaces (with features most like the super surface definition) were chosen as likely super surfaces. This study identified seven of these likely super surfaces in the Golden Throne region. These may be the same surfaces as those recognized by Capps (1990). However, there are other possible super surfaces within the sections; these 
have also been plotted on the Page Sandstone measured sections diagram but have not been highlighted (Appendix B, Plate 3).

After analyzing the digitized measured sections we found that our work differed substantially from work done by Capps (1990). These differences include the following observations:

- Thickness of members in the Page and lithology in his measured section (waterfall on Highway 24) do not match our measured sections.

- Super surfaces in some cases do not line up.

- Packages of rock between super surfaces do not maintain thickness laterally. Packages change thickness and lithology drastically over short distances.

- The Judd Hollow Tongue's thickness in our sections is much thinner than Capps' sections.

- A limestone bed within the Judd Hollow Tongue is not continuous south of Highway 24.

- Capps' total thickness is around 26 meters thick, actual thickness is around 41 meters.

These differences call into question the validity of Capps (1990) work in the Capitol Reef area. It suggests the following possibilities: his work in the Capitol Reef area is in error, measured section thickness have been underestimated, rock packages between super surfaces do in fact vary substantially in thickness, and the stratigraphy in the Capitol Reef area does not correlate to other studied areas.

After reviewing these observations we conclude that we can describe in detail the lithology and sedimentology of the Page Sandstone in the Golden Throne area. However, 
attempting to tie the findings of this study to Capps' regional stratigraphic framework is not possible because of problems found in Capps' data which do not match to our observations. What is needed in order to realistically correlate these surfaces to the Escalante/Boulder area, and the Page, Arizona/Lake Powell area is a study within the Capitol Reef area that contains the same density of measured sections as was conducted in other areas (Blakey et al., 1996, Capps 1990). Having measured sections at a higher density would permit identification of the number of super surfaces in the area, lateral extent of super surfaces, and test the validity of using super surfaces as stratigraphic markers in the Capitol Reef area. This study should be accomplished down the spine of the Waterpocket Fold in the area in between Capitol Reef and the Colorado River. With this information, detailed analysis of lateral changes in super surface morphology and facies changes could be tracked and meaningful comparisons could be made.

\section{CONCLUSIONS}

Study of the Jurassic Page Sandstone in the Golden Throne Quadrangle has led to the following conclusions:

- The Page Sandstone is composed of two members; the Harris Wash Member and the Thousand Pockets Member, which is divided by the Judd Hollow Tongue, a member of the overlying Carmel Formation.

- It is primarily composed of eolian sandstone with smaller amounts of siltstone, shale, and limestone.

- The Page Sandstone lies directly above the Navajo Sandstone. This contact has been called the J2 unconformity and displays pervasive polygonal fractures. 
- Study of the formation within the Golden Throne Quadrangle was beneficial in understanding the local characteristics that have aided in the map-making process.

- In other places where it has been studied a stratigraphic framework has been developed. Our findings show discrepancies between our work and the work of Capps' (1990) which do not permit our research to be tied into his stratigraphic framework.

- In order to better understand the regional sedimentology of the Page Sandstone more sections need to be measured at higher density so that the number and lateral extent of super surfaces can be determined. This in turn will determine the validity of using super surfaces as stratigraphic markers as they are presently defined (Kocurek, 1988) in the Capitol Reef area. 


\section{REFRENCES}

Blakey, R.C., Havholm, K.G., and Jones, L.S., 1996, Stratigraphic analysis of eolian interactions with marine and fluvial deposits, Middle Jurassic Page Sandstone and Carmel Formation, Colorado Plateau, USA: Journal of Sedimentary Research, v. 66, n. 2, p. 324-342.

Capps, D.M., 1990, Presence and significance of regional bounding surfaces and genetic sequences in an eolian sandstone: Page Sandstone (Jurassic), south-central Utah: Master's Thesis, Northern Arizona University.

Havholm, K.G., and Kocurek, G., 1994, Factors controlling aeolian sequence stratigraphy: clues from super bounding surface features in the Middle Jurassic Page Sandstone: Sedimentology, v. 41, p. 913-934.

Jones, S.L., and Blakey, R.C., 1997, Eolian-fluvial interaction in the Page Sandstone (Middle Jurassic) in south-central Utah, USA- a case study of erg margin processes: Sedimentary Geology, v. 109, p. 181-198.

Kocurek, G., 1988, First-order and super bounding surfaces in eolian sequences-bounding surfaces revisited: Sedimentary Geology, 56, p. 193-206.

McLelland, B.E., Morris, T.H., and Martin, D.H., 2002, Geologic Map of the Fruita Quadrangle, Wayne County, Utah: Utah Geological Survey, in press.

Pipiringos, G.N., and O’Sullivan, R.B., 1978, Principle unconformities in Triassic and Jurassic rocks, western United States - a preliminary study. United States Geologic Survey Professional Paper 1035-A, p. 29 


\section{APPENDICIES}

\section{APPENDIX A}

APPENDIX A-Plate 1. Geologic Map of the Golden Throne Quadrangle

APPENDIX A-Plate 2. Legend for the map of the Golden Throne Quadrangle

including the following:

- A description of map units

- A geologic cross-section

- A lithologic column depiction of mapped units

- A diagram showing correlation of map units age

- A key explaining map symbols 


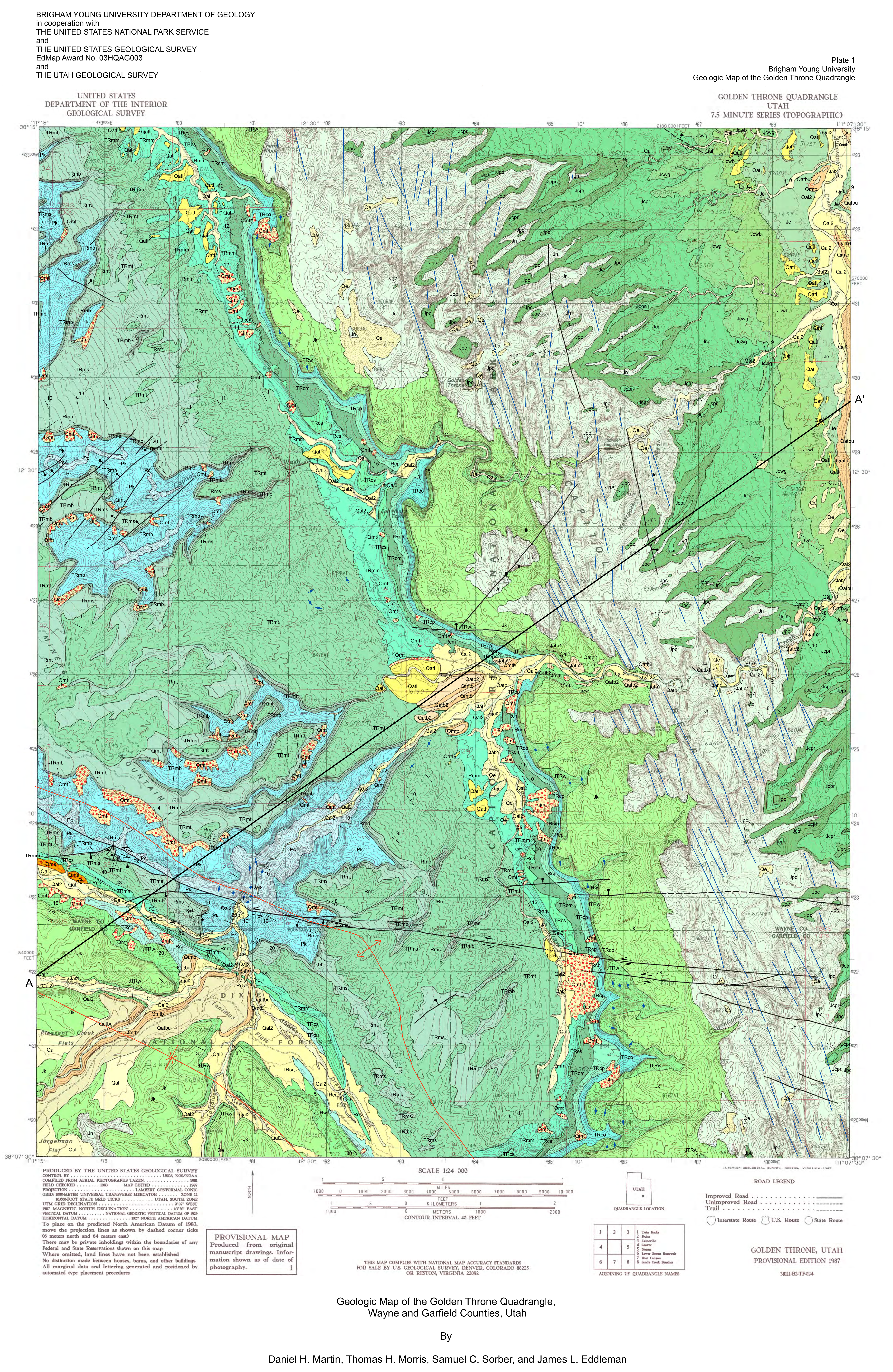




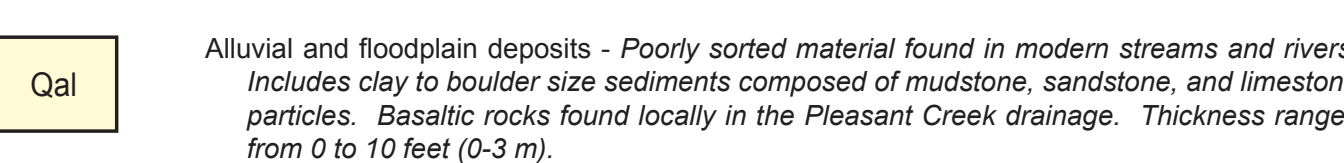

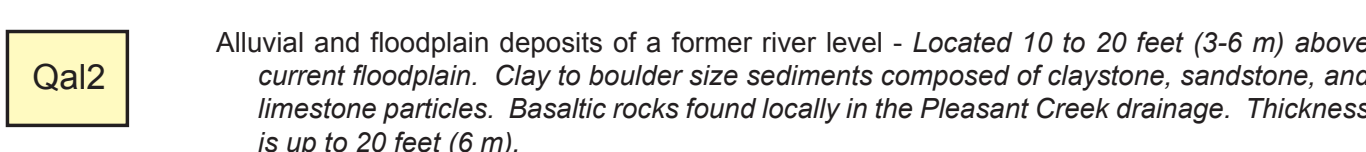

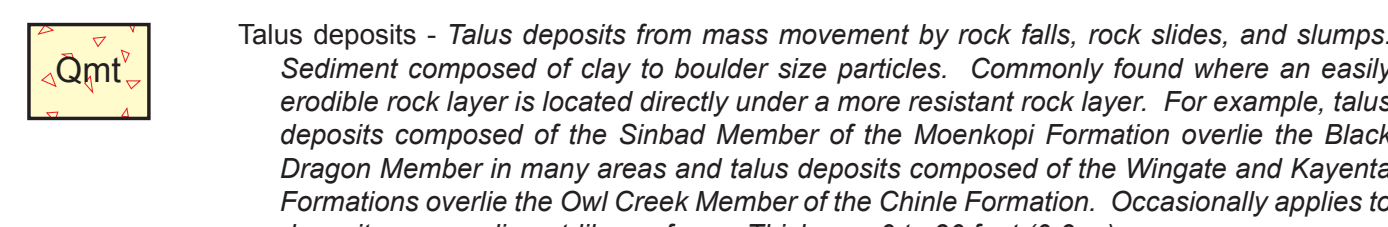

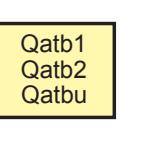

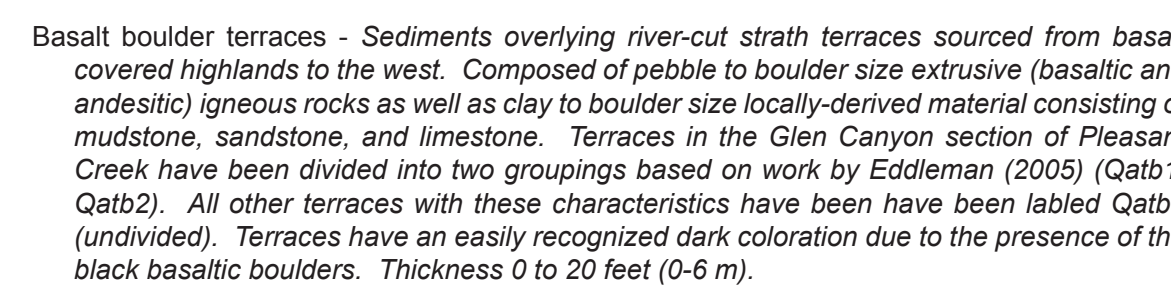
amt
amit

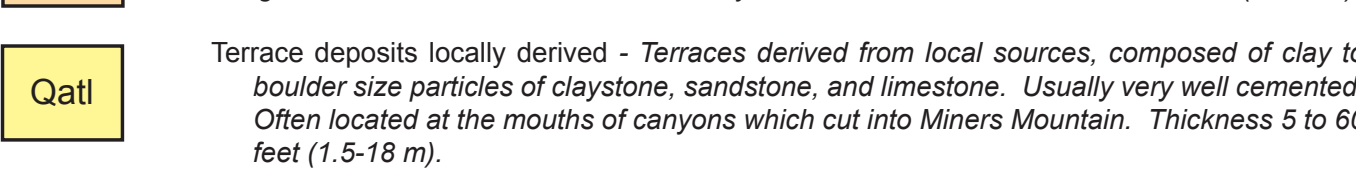

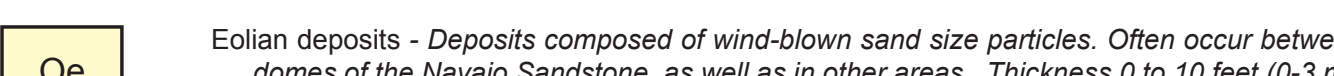

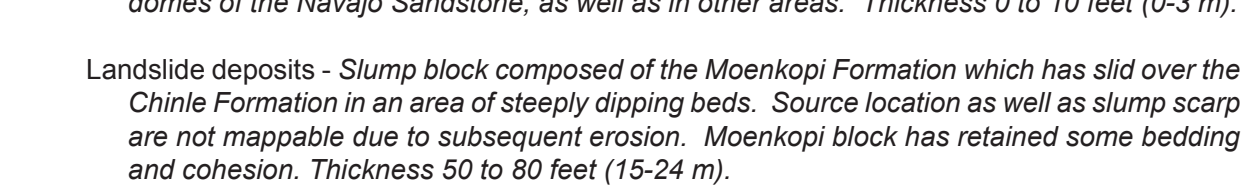

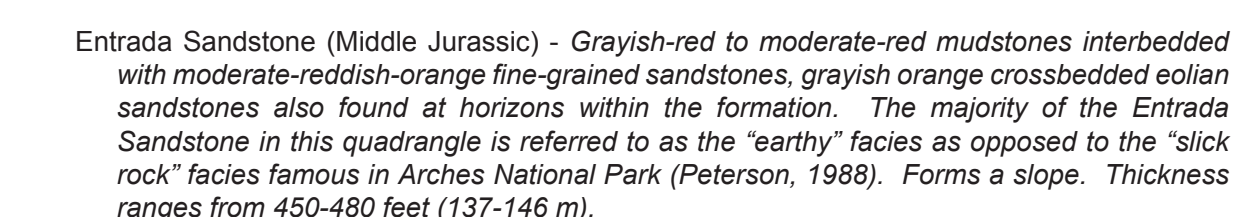

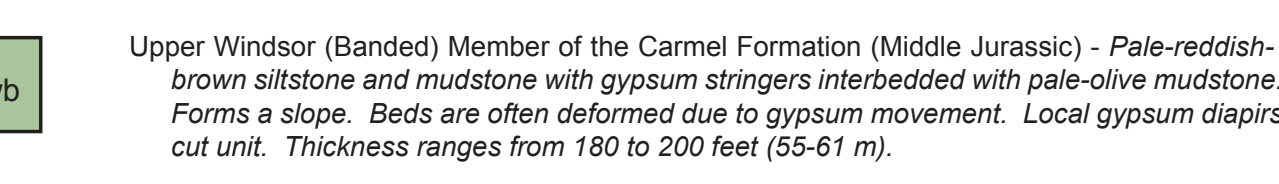

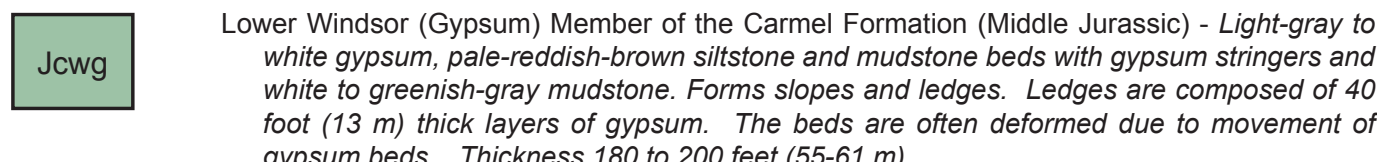

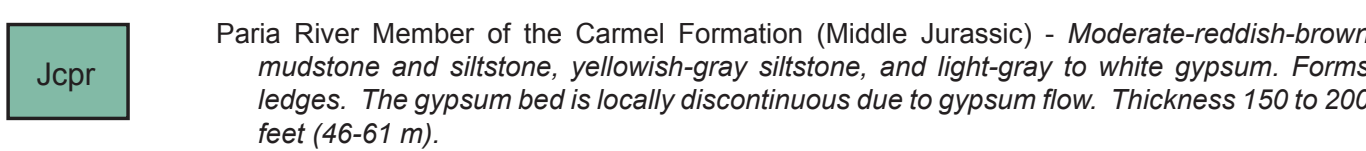
soc

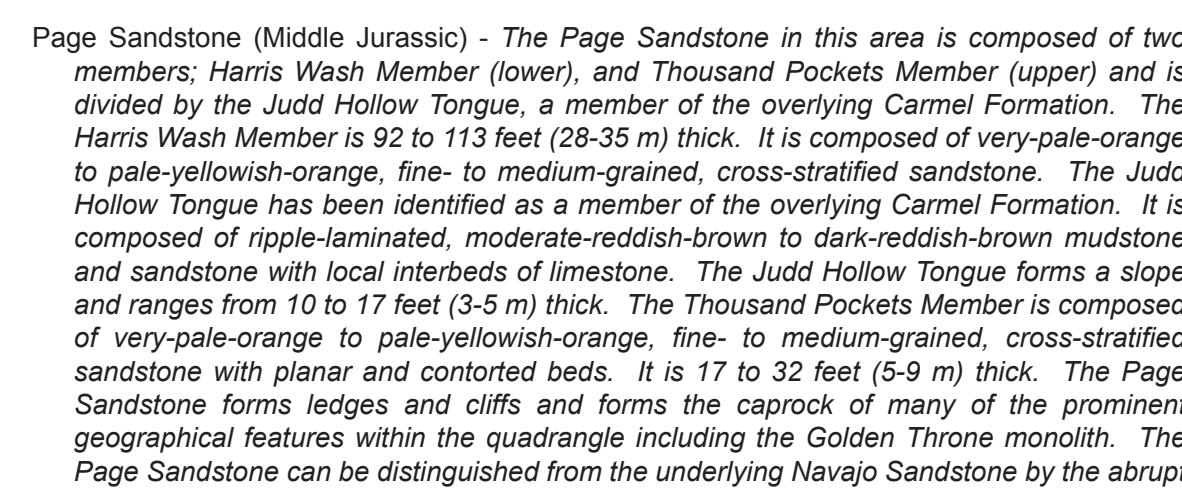

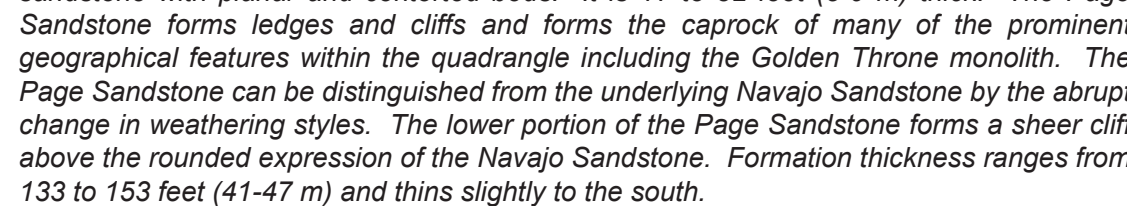
$\mathrm{Jn}$
$\mathrm{Jn}$

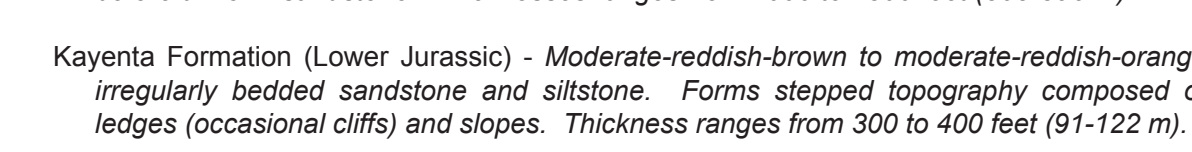

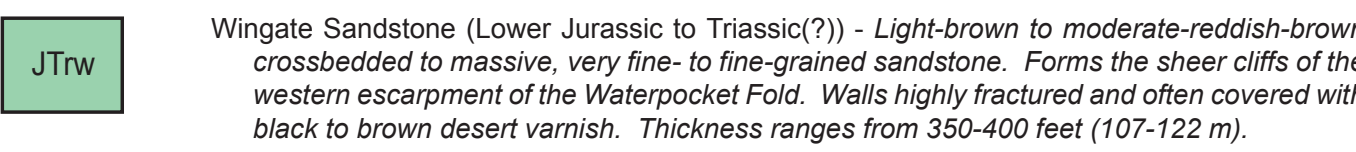

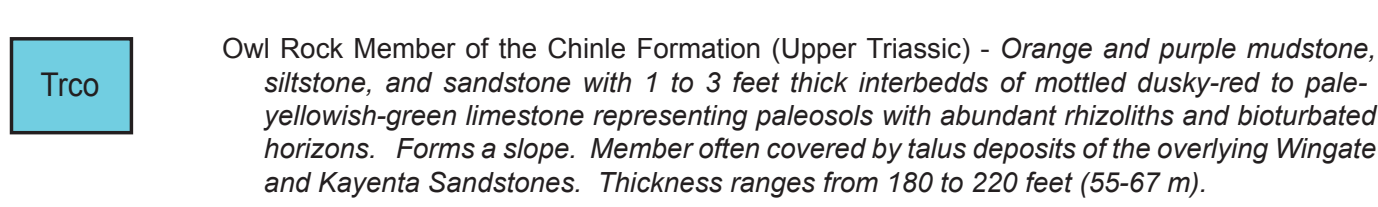

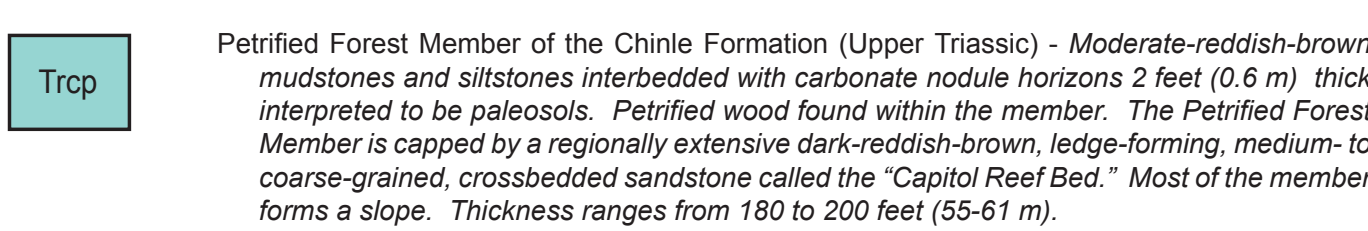

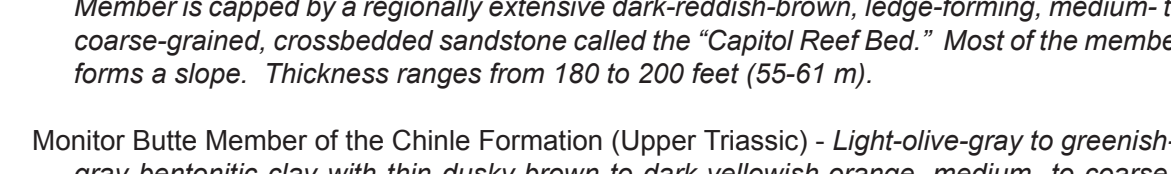

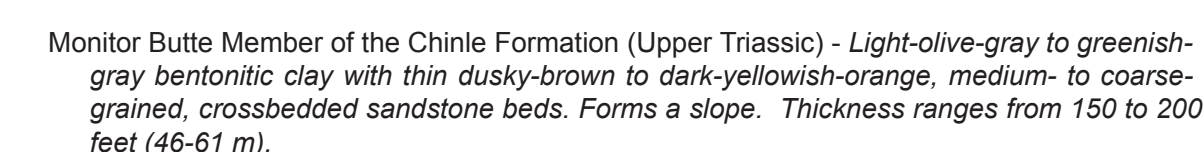

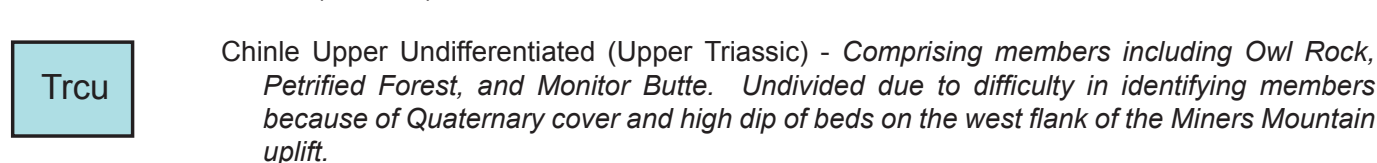
\begin{tabular}{|l|l}
\hline Tres \\
Tres
\end{tabular}

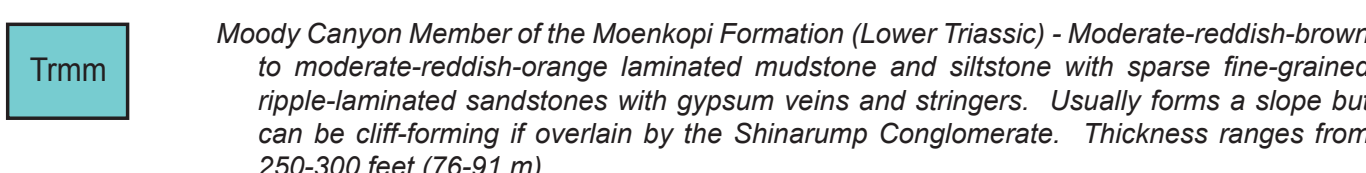

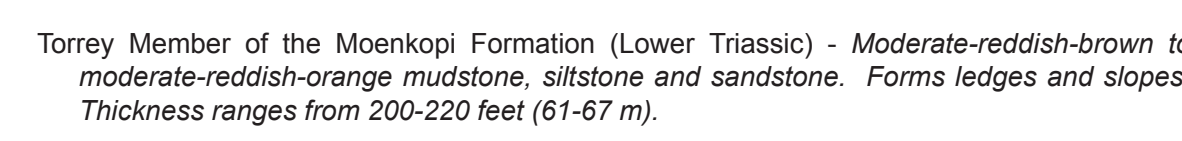

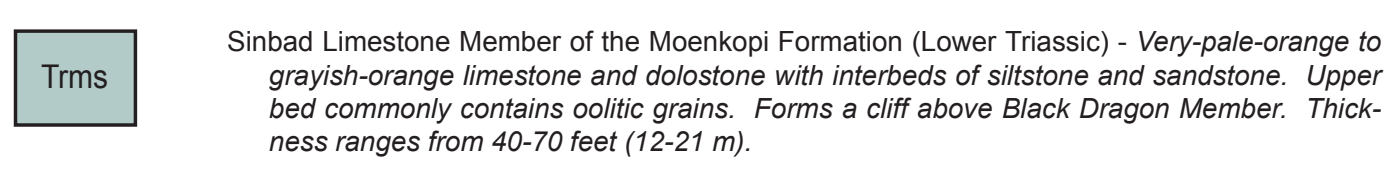

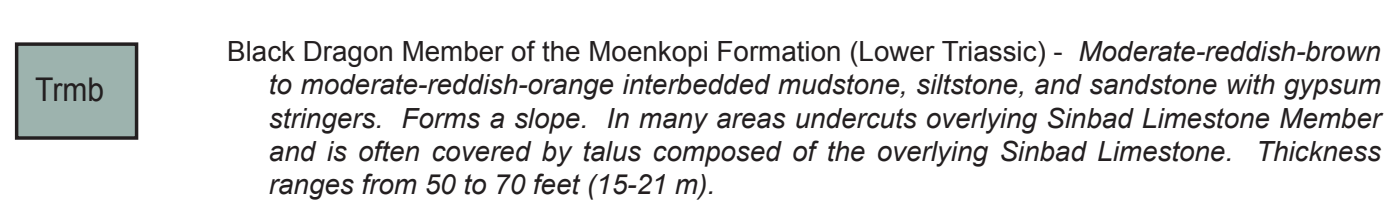

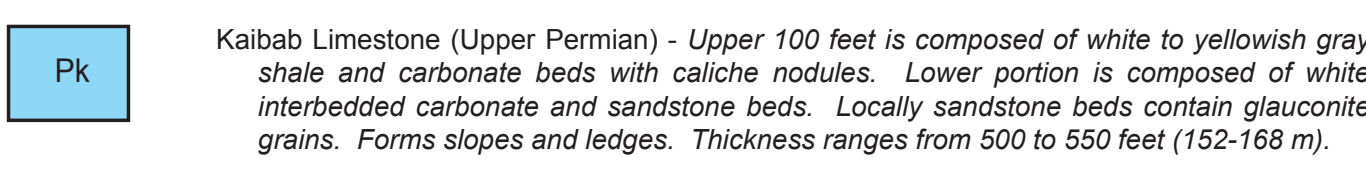

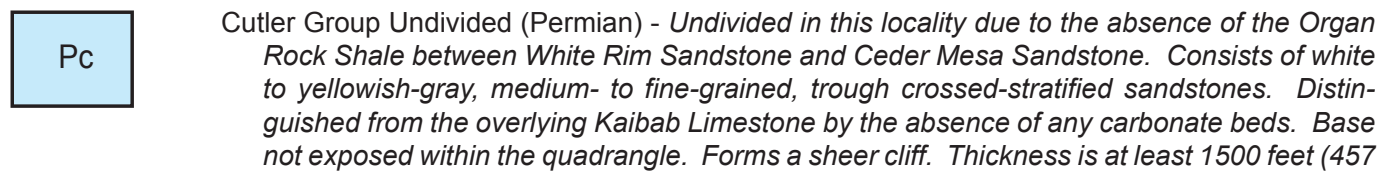

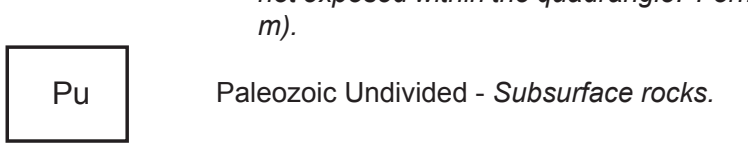

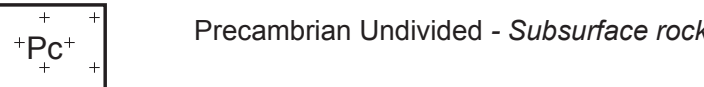

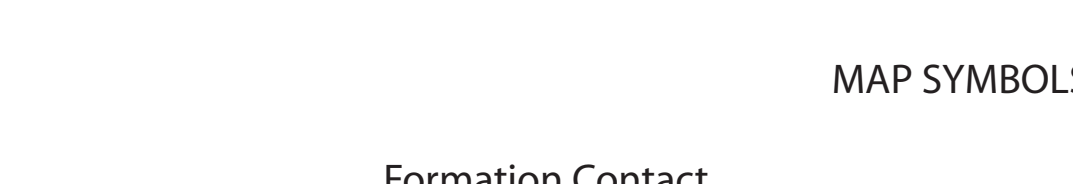

Faut - bar and ball on the downthrown block; dashed whe

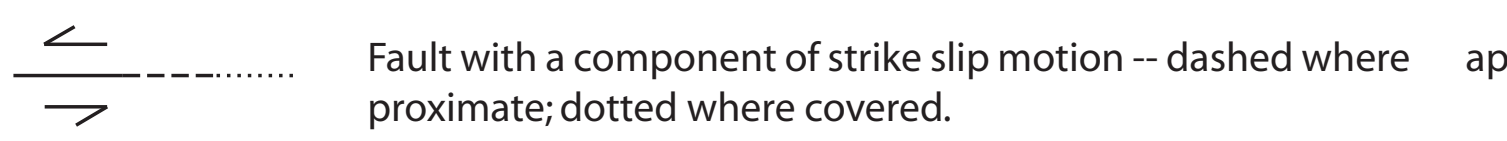

* Anticline - showing trace of the axial plain of the Miners Mount

$\uparrow$ syncline - showing trace of the axial plain.

$A-A^{\prime}$ Line of Cross Section

Joints - showing areas with prominent joint sets

Joints within the Navajo Sandstone

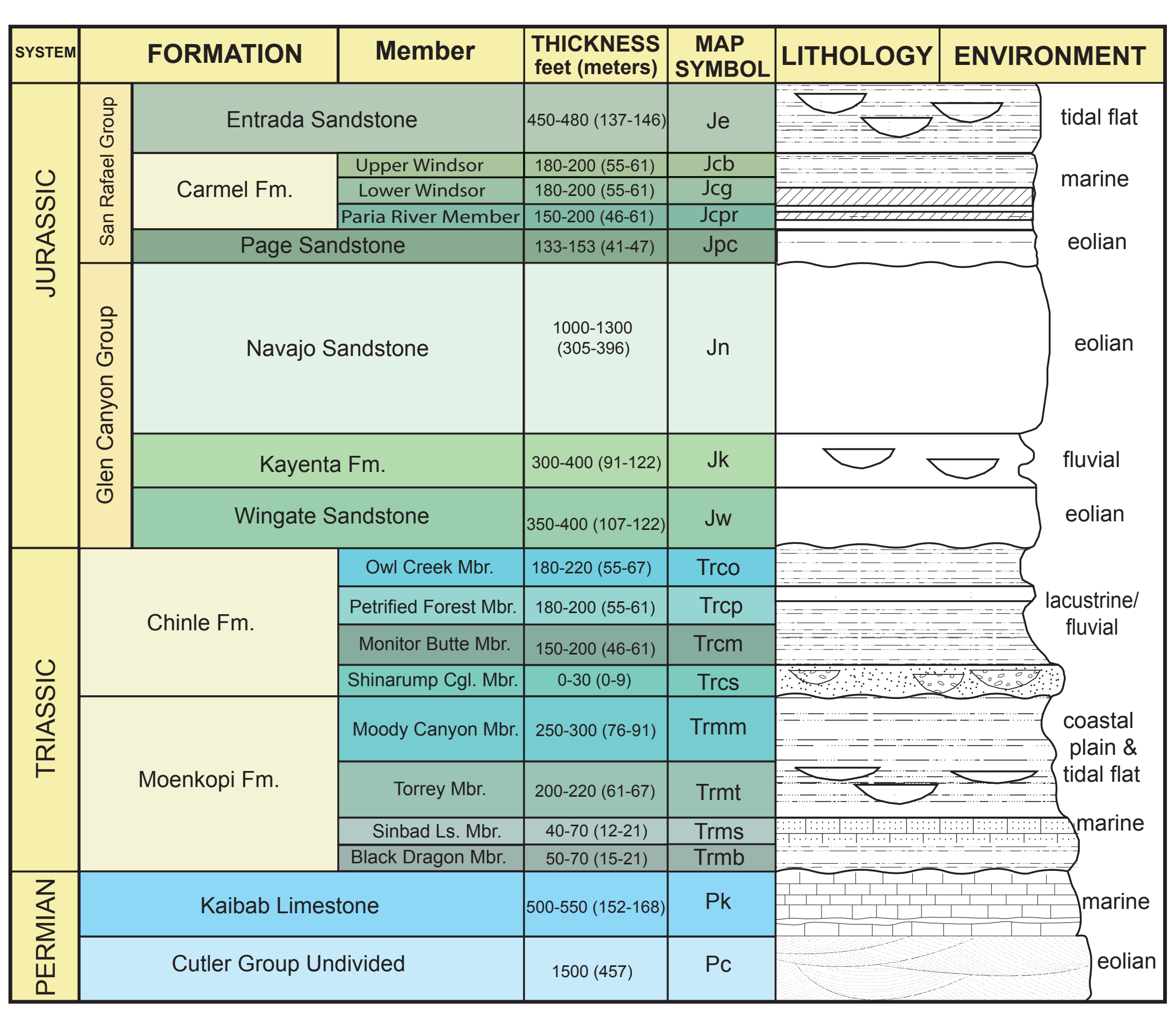

CORRELATION OF MAP UNITS
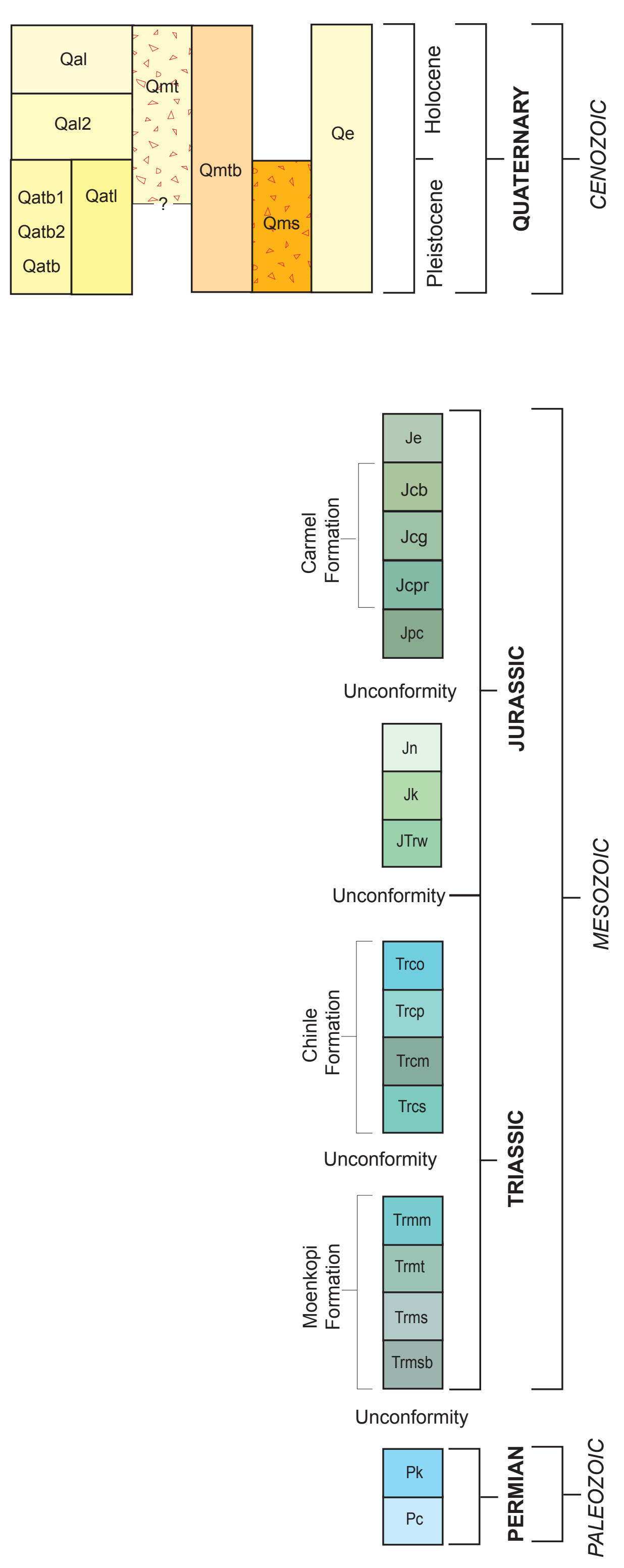

Basalt Boulder Terrace Information

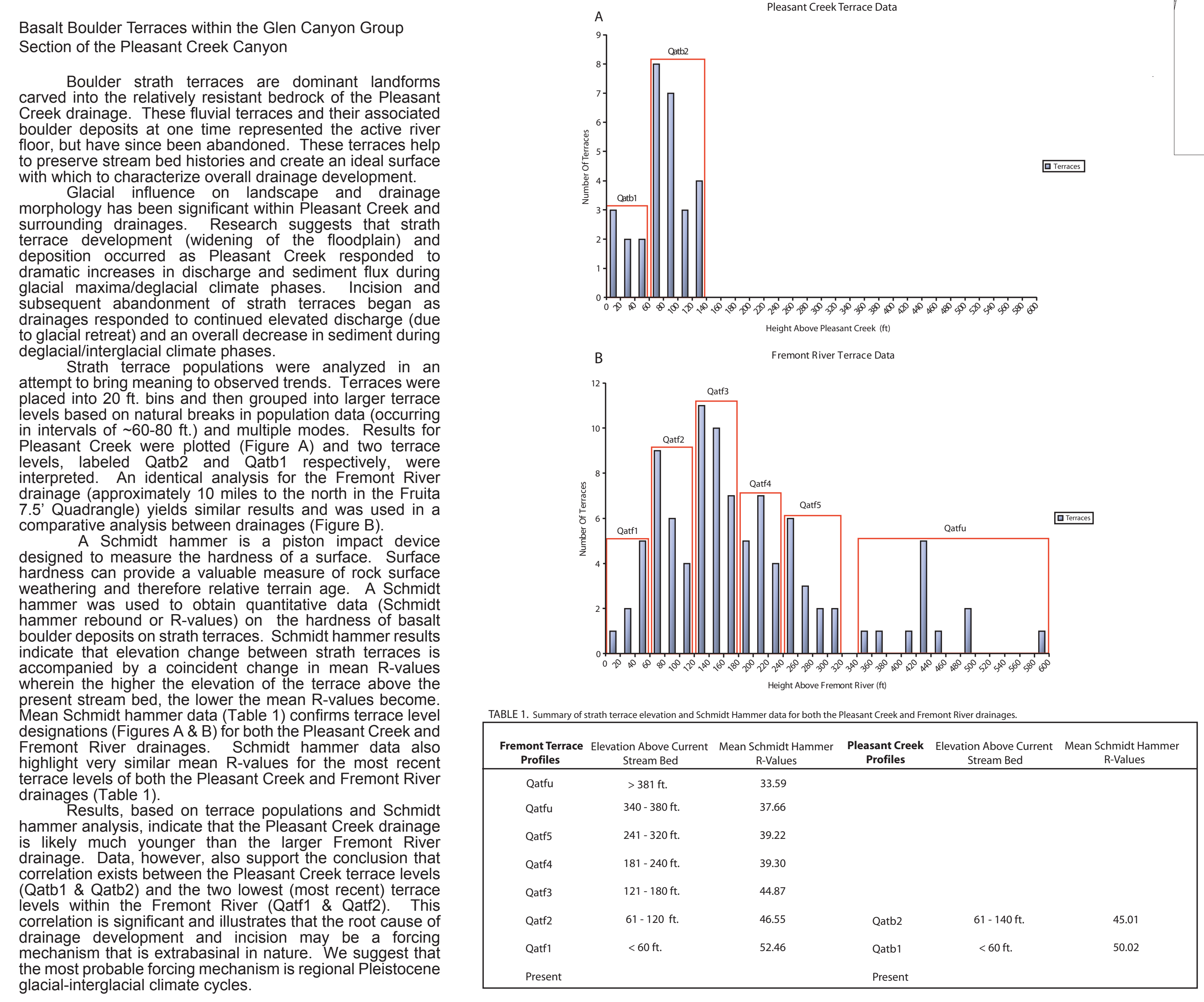

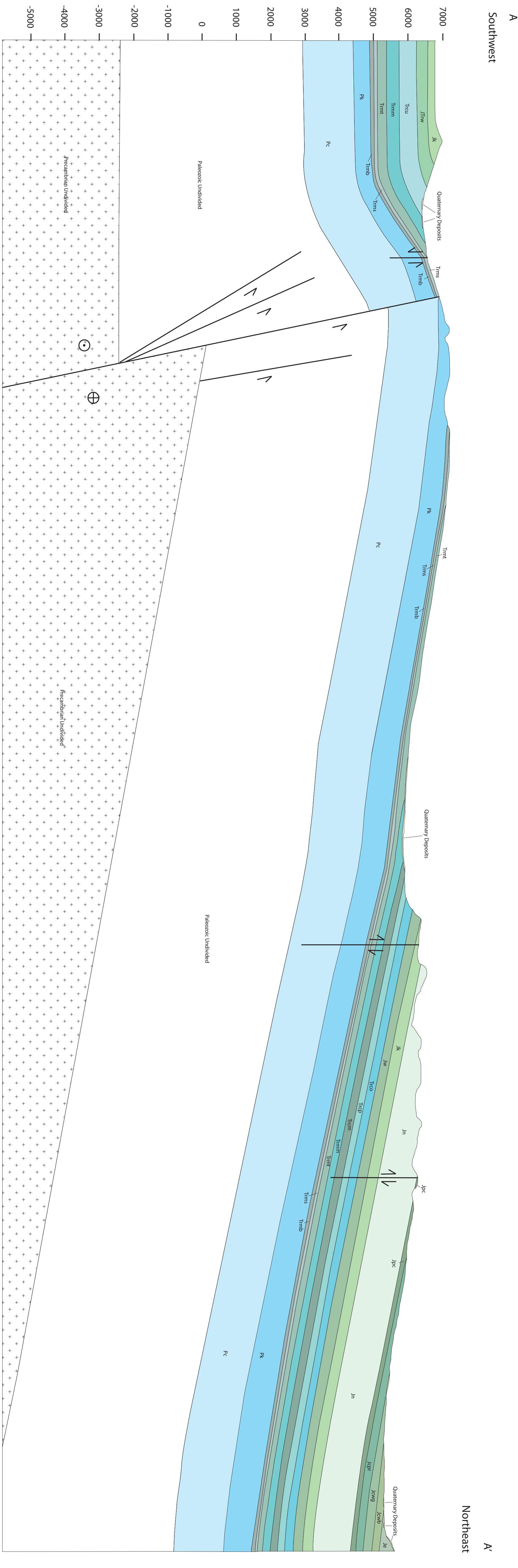

旁 


\section{APENDIX B}

APPENDIX B-Plate 3. Page Sandstone Correlation Chart 
Page Sandstone Drafted Sections

Pections

Brigham Young University

Geologic Map of the Golden Throne Quadrangle

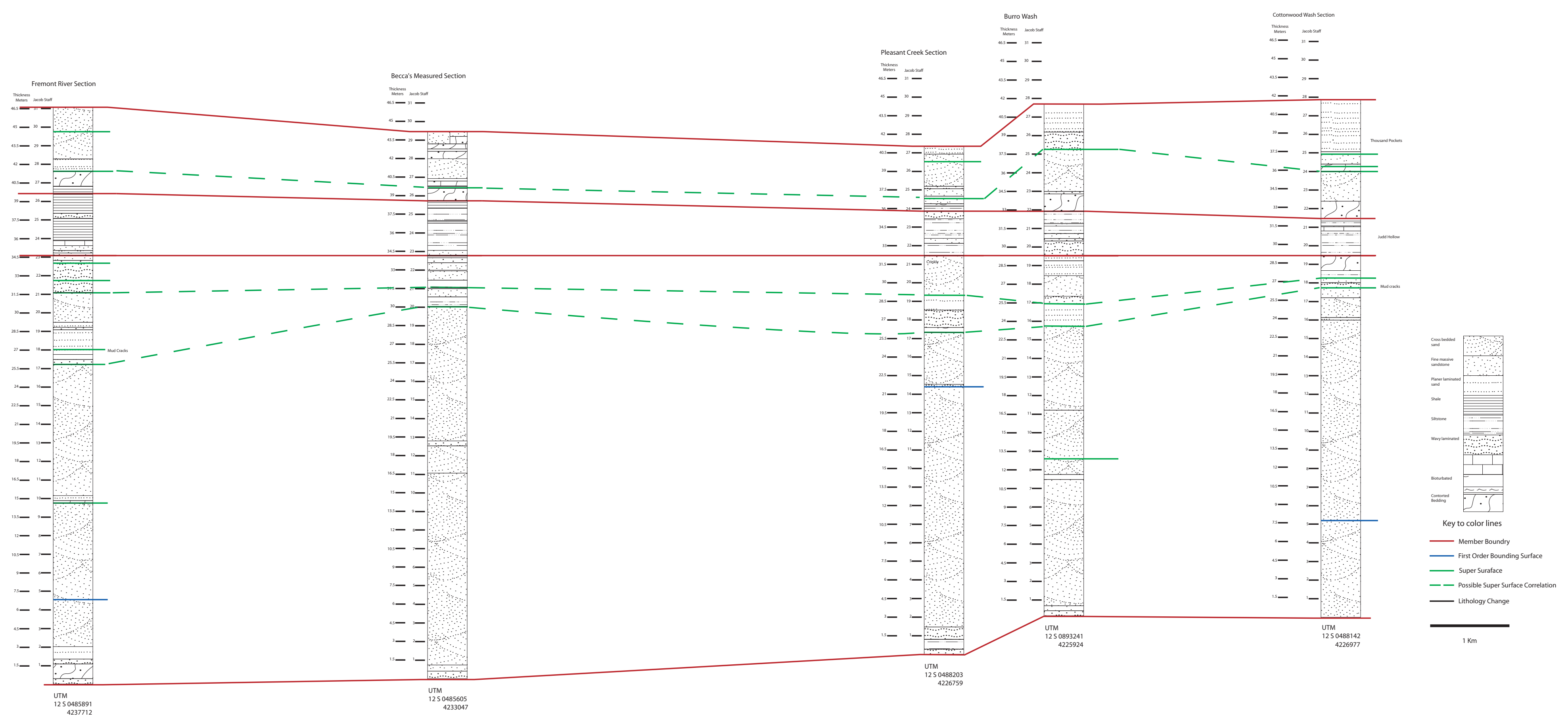




\section{APPENDIX C}

APPENDIX $\mathrm{C}$ - $\mathrm{A}$ data $\mathrm{CD}$ containing the following information:

- The Golden Throne Quadrangle, Wayne and Garfield Counties, Utah (ESRI ArcView 9.3)

- Map Legend and Key of the Geologic map of the Golden Throne Quadrangle(Adobe Illustrator CS 1.3)

- $\quad$ Page Sandstone Correlation Chart (Adobe Illustrator CS 1.3)

- Digital version of this thesis (Adobe PDF) 
APPENDIX D

Selected Photos from the Golden Throne Quadrangle

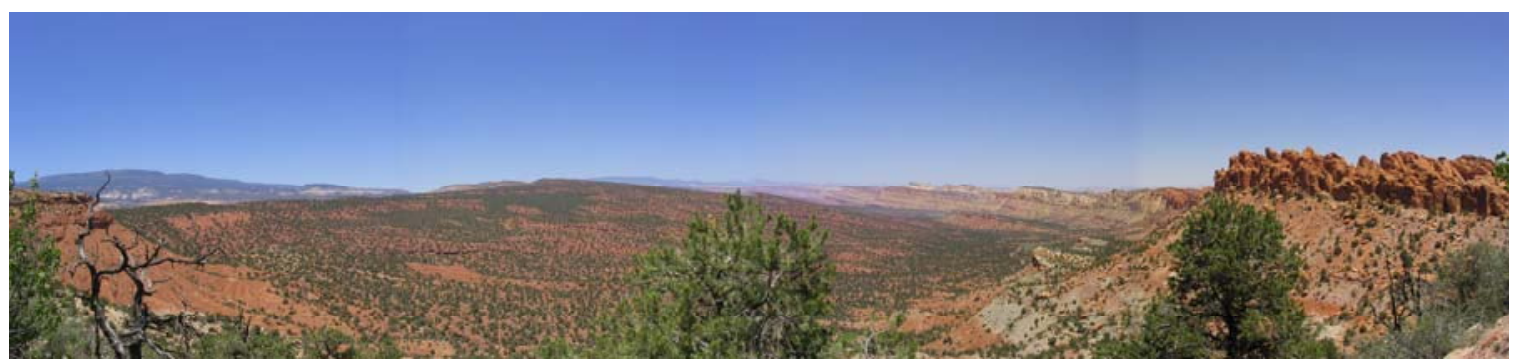

Photo 1. Photo taken looking north into the interior of the Miners Mountain Uplift. Photo montage taken near the south boarder of the quadrangle near Cottonwood Canyon.

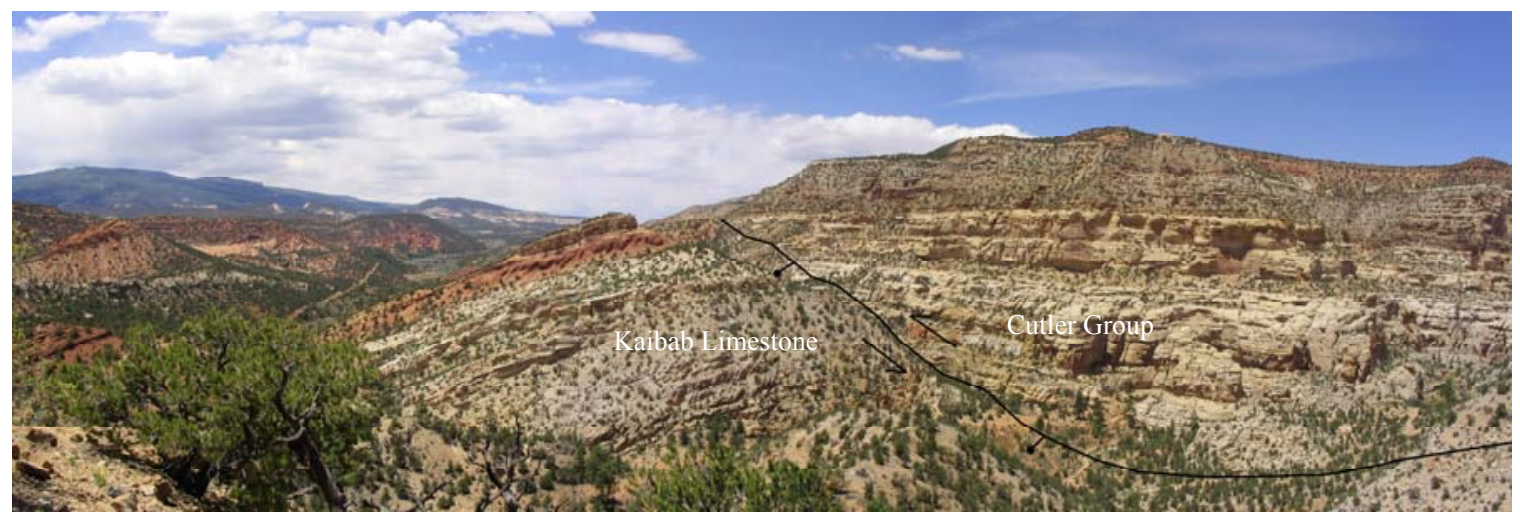

Photo 2. Photo montage taken looking north from the south side of Pleasant Creek. Annotation shows the trace and relative movement along the Teasdale Fault. Also showing the juxtaposition of the Kaibab Limestone against the Cutler Group Sandstones. 


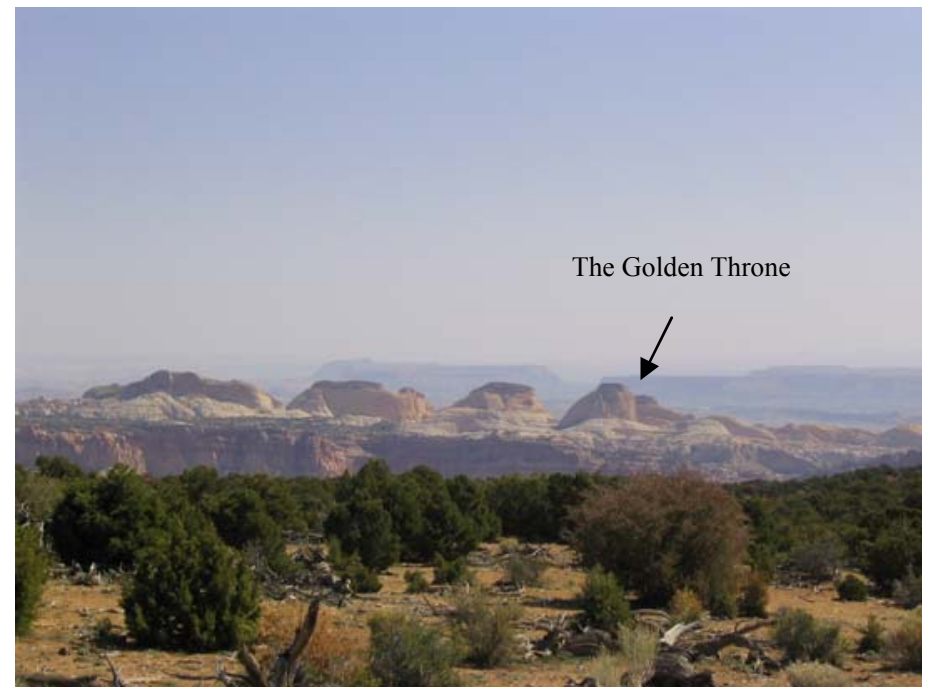

Photo 3. Photo taken looking east toward the western escarpment of the Waterpocket Fold from Miners Mountain. White knobs are composed of Navajo Sandstone.

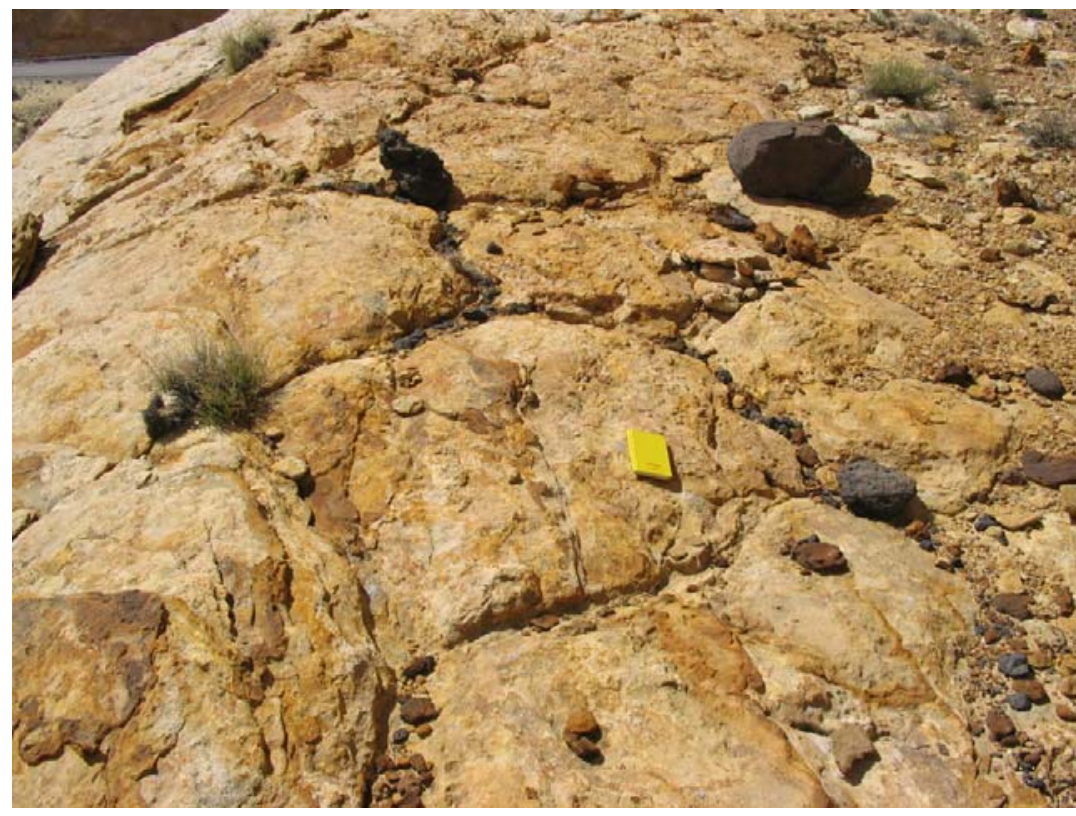

Photo 4. Photo taken at the J2 unconformity at the Fremont River near the waterfall. This photo displays the large scale polygonal cracks which are characteristic of the contact between the Navajo Sandstone and the Page Sandstone. 


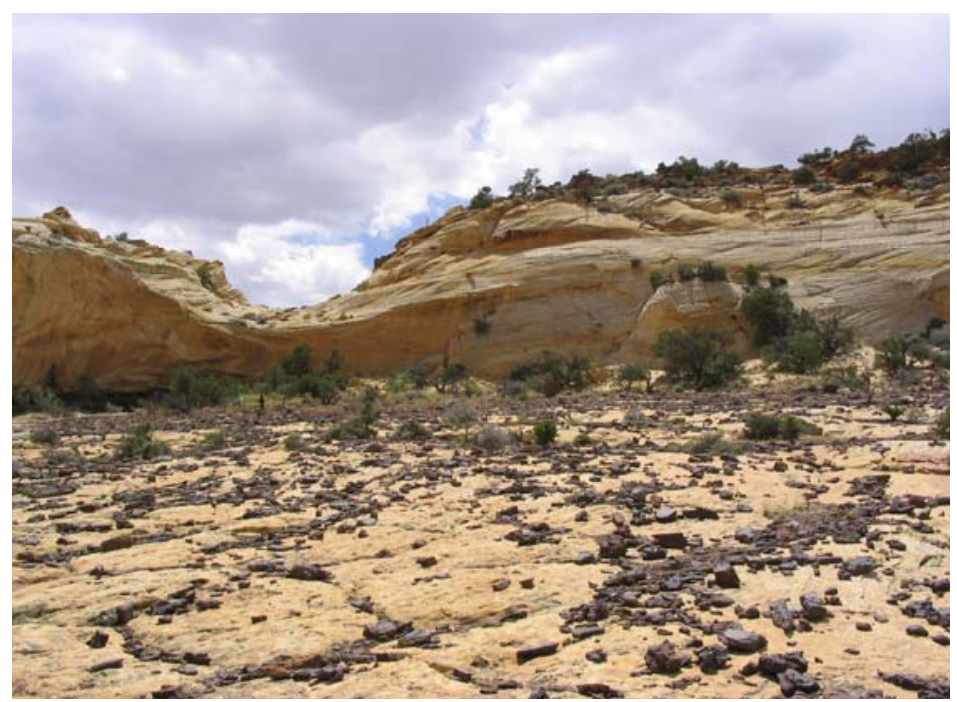

Photo 5. Photo taken at the contact of the Navajo Sandstone and the Page Sandstone near Pleasant Creek. This contact is known as the $\mathrm{J} 2$ unconformity. Large scale polygonal fractures characteristic of the contact. Black rocks appearing in this photo are mineralized sandstone which has eroded out of joints in the Page Sandstone.

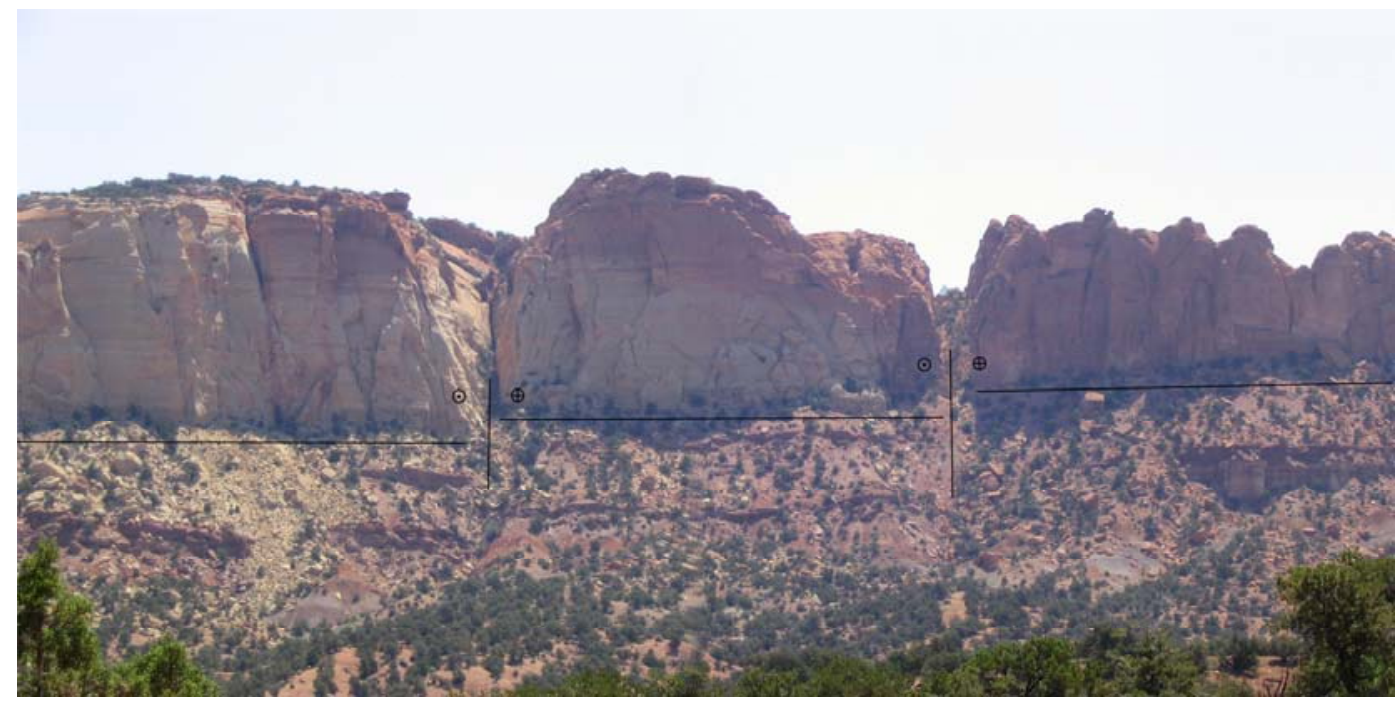

Photo 6. Photo taken looking east toward the Western Escarpment of the Waterpocket Fold at locality where strike-slip faults cross the escarpment. Note appearance of normal offset. This phenomenon is caused by an erosional illusion. 


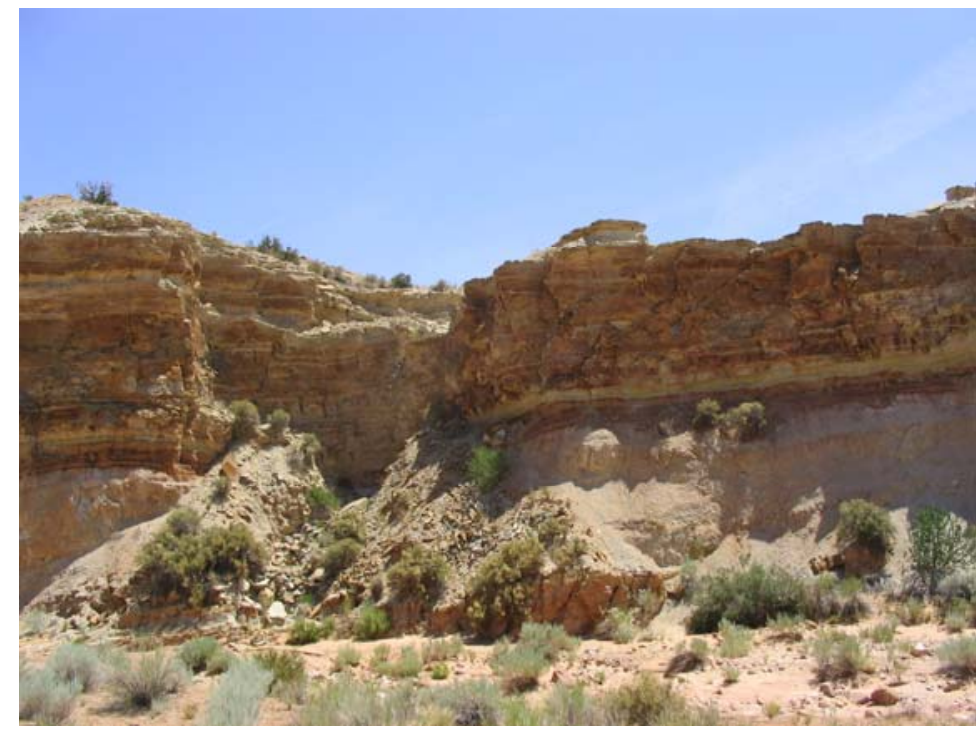

Photo 7. Photo taken looking south. Fault graben located within the Carmel Formation. Caused by gypsum withdraw.

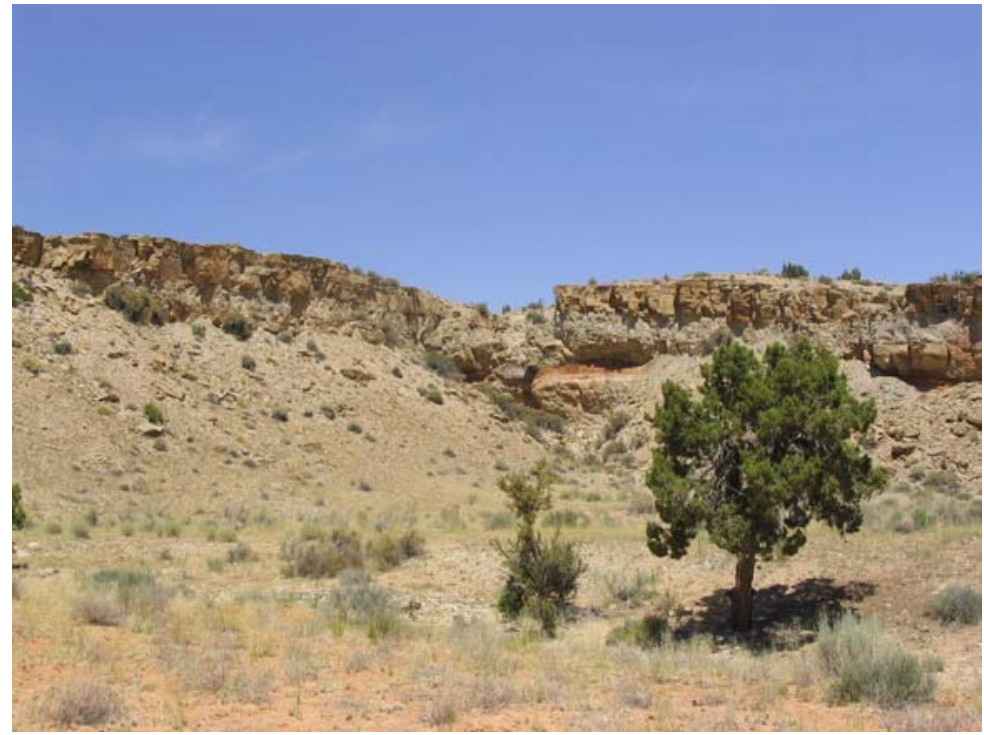

Photo 8. Photo taken looking north within the Carmel Formation. Same fault zone associated with previous photo. Caused by gypsum withdraw. 


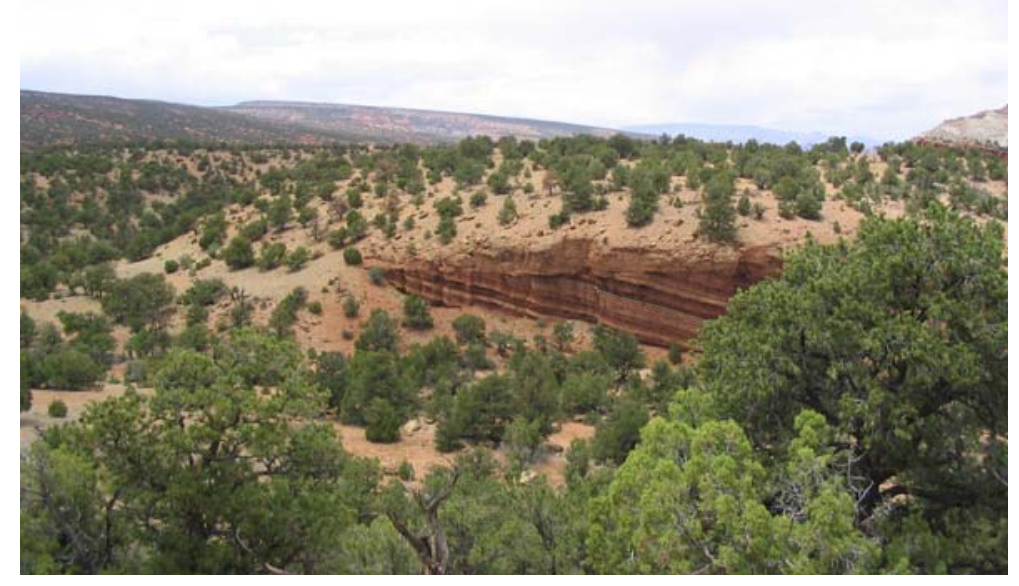

Photo 9. Photo taken looking north. Angular unconformity juxtaposing a fluvial terrace composed of locally derived material (Qatl) deposits, and the Moody Canyon Member of the Moenkopi Formation.

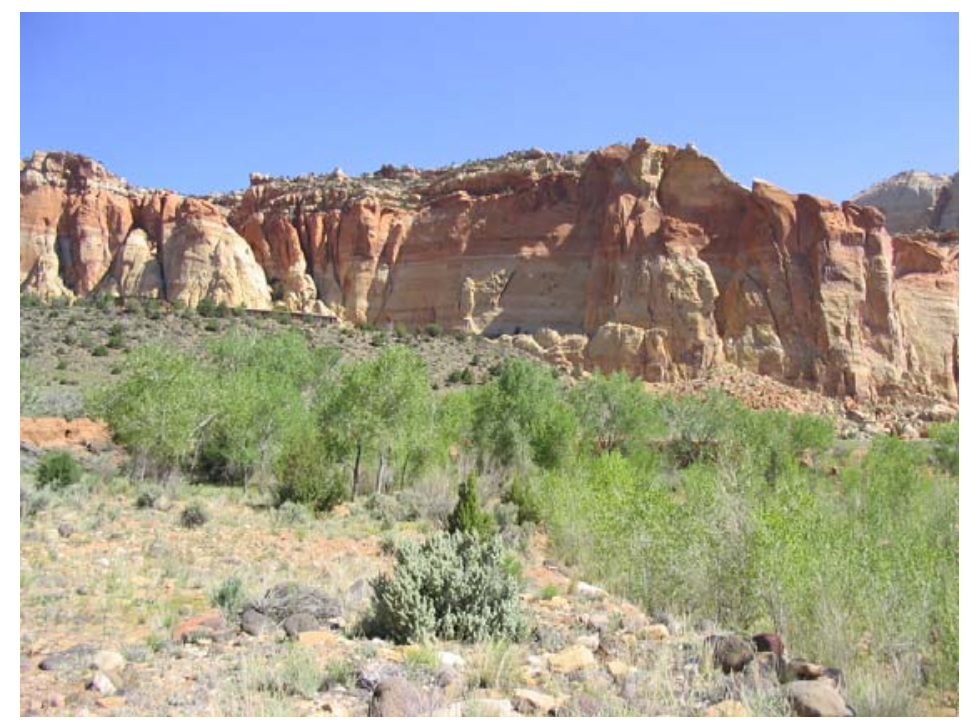

Photo 10. Photo taken looking east toward the western escarpment of the Waterpocket Fold near Pleasant Creek. Displaying basalt boulders and Basalt Boulder Terraces (Qatb) deposits. 